Prepared in cooperation with the Yakama Nation, Bureau of Reclamation, and Washington State Department of Ecology

\title{
Evaluation of Sockeye Salmon after Passage through an Innovative Upstream Fish-Passage System at Cle Elum Dam, Washington, 2017
}

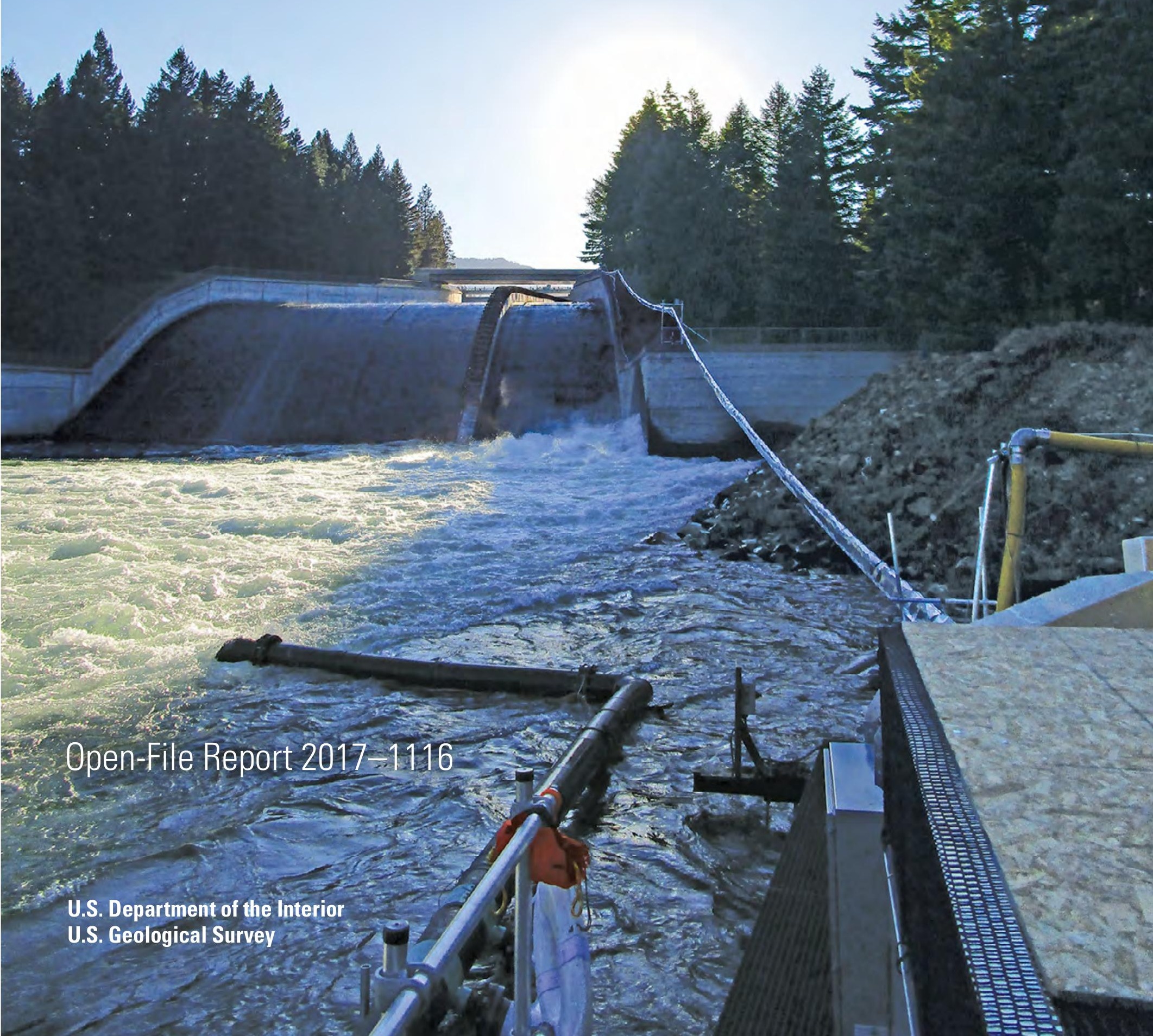


Cover: Photograph showing Whooshh Fish Transport System used to pass adult sockeye salmon at Cle Elum Dam, Washington. Photograph by Tobias J. Kock, U.S. Geological Survey, July 15, 2017. 


\section{Evaluation of Sockeye Salmon after Passage through an Innovative Upstream Fish-Passage System at Cle Elum Dam, Washington, 2017}

By Tobias J. Kock, Scott D. Evans, Amy C. Hansen, Russell W. Perry, Hal C. Hansel, Philip V. Haner, and Ryan G. Tomka

Prepared in cooperation with the Yakama Nation, Bureau of Reclamation, and Washington State Department of Ecology

Open-File Report 2018-1116

U.S. Department of the Interior U.S. Geological Survey 


\title{
U.S. Department of the Interior \\ RYAN K. ZINKE, Secretary
}

\author{
U.S. Geological Survey \\ James F. Reilly II, Director
}

U.S. Geological Survey, Reston, Virginia: 2018

For more information on the USGS—-the Federal source for science about the Earth, its natural and living resources, natural hazards, and the environment-visit https://www.usgs.gov/ or call 1-888-ASK-USGS (1-888-275-8747).

For an overview of USGS information products, including maps, imagery, and publications, visit https:/store.usgs.gov.

Any use of trade, firm, or product names is for descriptive purposes only and does not imply endorsement by the U.S. Government.

Although this information product, for the most part, is in the public domain, it also may contain copyrighted materials as noted in the text. Permission to reproduce copyrighted items must be secured from the copyright owner.

Suggested citation:

Kock, T.J., Evans, S.D., Hansen, A.C., Perry, R.W., Hansel, H.C., Haner, P.V., and Tomka, R.G., 2018, Evaluation of sockeye salmon after passage through an innovative upstream fish-passage system at Cle Elum Dam, Washington, 2017: U.S. Geological Survey Open-File Report 2018-1116, 30 p., https://doi.org/10.3133/ofr20181116.

ISSN 2331-1258 (online) 


\section{Contents}

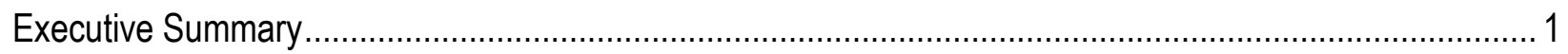

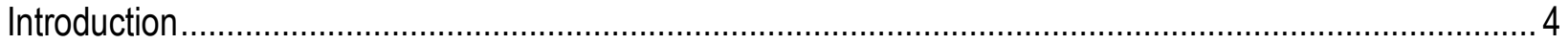



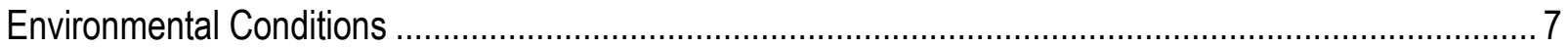

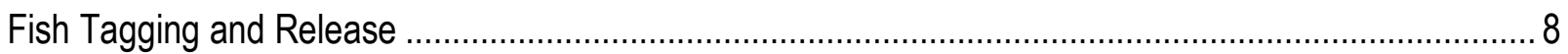

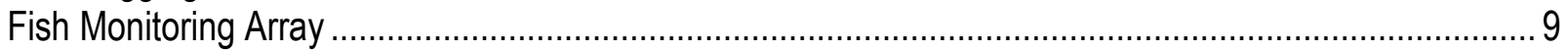

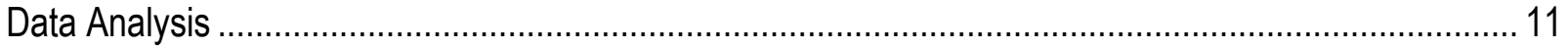

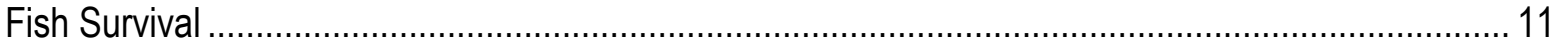

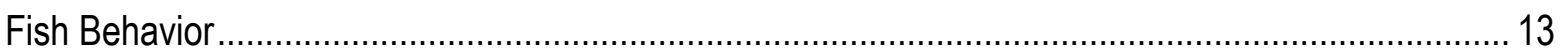

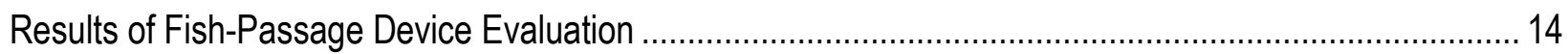

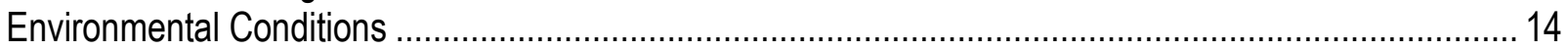

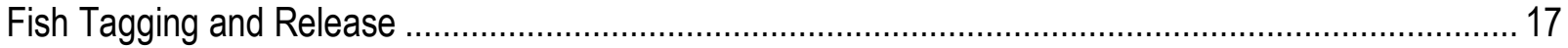

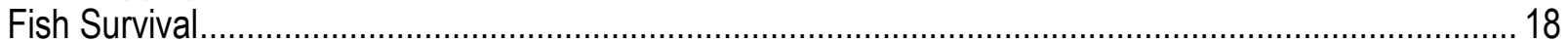

Behavior of Fish Released Downstream of Cle Elum Reservoir....................................................... 21

Behavior of Fish Released into Cle Elum Reservoir ....................................................................... 21

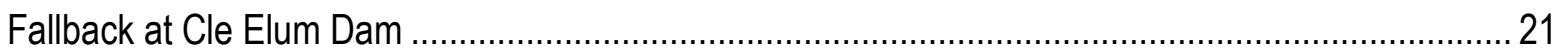

Upstream Movement from Cle Elum Reservoir........................................................................ 22

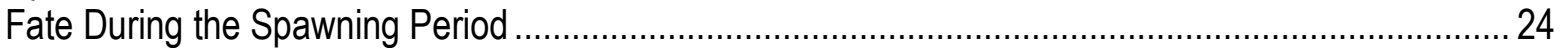

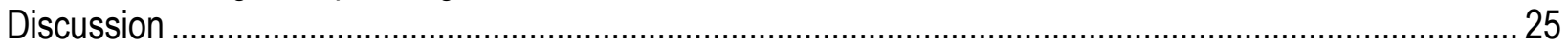

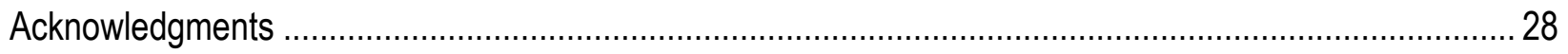

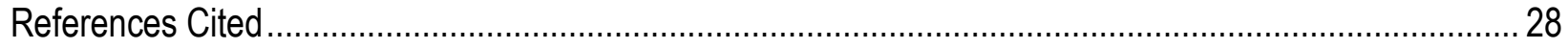

\section{Figures}

Figure 1. Locations of Roza Dam on the Yakima River, and Cle Elum Dam on the Cle Elum River, a tributary of the Yakima River, Washington................................................................................. 5

Figure 2. Components of the Whooshh Fish Transport System in the tailrace of Cle Elum Dam,

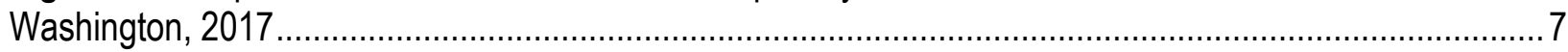

Figure 3. Locations of monitoring sites used to detect tagged fish in the reach between Roza and Cle Elum Dams, and in Cle Elum Reservoir and Cle Elum River upstream of the reservoir, Washington. ........ 10

Figure 4. Daily average water temperature during the study release period at eight depths in the forebay of Cle Elum Dam, Washington, 2017.

Figure 5. Daily discharge from and forebay elevation of water surface level at Cle Elum Dam, JulyDecember 2009-17.

Figure 6. Estimates of Cormack-Jolly-Seber single-release survival probability for adult sockeye salmon passed through a Whooshh Fish Transport System or released directly into Cle Elum Reservoir at a reservoir release site, Washington, July 14 and July 17-19, 2017

Figure 7. Estimates of Cormack-Jolly-Seber paired-release survival probability for Whooshh Fish Transport System survival for adult sockeye salmon released into Cle Elum Reservoir, Washington, July 14 and July 17-19, 2017

Figure 8. Effect of fork length on survival probability estimates of adult sockeye salmon passed through a Whooshh Fish Transport System or released at a reservoir release site in Cle Elum Reservoir, Washington, July 19, 2017

Figure 9. Cumulative timing of fallback by radio-tagged adult sockeye salmon at Cle Elum Dam, Washington, 2017 ... 
Figure 10. Cumulative timing of upstream movement by radio-tagged adult sockeye salmon from Cle Elum Reservoir to Cle Elum River, Washington, 2017

Figure 11. Percentage of tagged adult sockeye salmon as a function of the farthest upstrea detection in Cle Elum River, Washington, 2017

\section{Tables}

Table 1. Daily mean water temperature in the forebays of Priest Rapid and Roza Dams, in the holding gallery near the Whooshh Fish Transport System entrance, and in the forebay of Cle Elum Dam, when adult sockeye salmon were collected and tagged for an evaluation in Cle Elum Reservoir, Washington, July 2017

Table 2. Number and origin of adult sockeye salmon tagged and released during the study at Roza and Cle Elum Dams, the Whooshh Fish Transport System, and Cle Elum Reservoir, Washington, July 2017.

Table 3. Summary of capture histories for adult tagged sockeye salmon passed into Cle Elum Reservoir through a Whooshh Fish Transport System or released at a shoreline release site, Washington, 2017.

Table 4. Parameter estimates from the Cormack-Jolly-Seber mark-recapture model used to estimate survival of tagged adult sockeye salmon released into Cle Elum Reservoir, Washington, 2017

Table 5. Number of upstream trips by radio-tagged adult sockeye salmon from Cle Elum Reservoir to Cle Elum River, Washington, 2017

Table 6. Number of radio-tagged adult sockeye salmon assigned to four fate groups during the spawning period near Cle Elum Reservoir, Washington, 2017. 


\section{Conversion Factors}

U.S. customary units to International System of Units

\begin{tabular}{lll}
\hline \multicolumn{1}{c}{ Multiply } & By & To obtain \\
\hline & Length & \\
\hline foot $(\mathrm{ft})$ & 0.3048 & meter $(\mathrm{m})$ \\
\hline & Flow rate & \\
\hline cubic foot per second $\left(\mathrm{ft}^{3} / \mathrm{s}\right)$ & 0.02832 & cubic meter per second $\left(\mathrm{m}^{3} / \mathrm{s}\right)$ \\
\hline
\end{tabular}

International System of Units to U.S. customary units

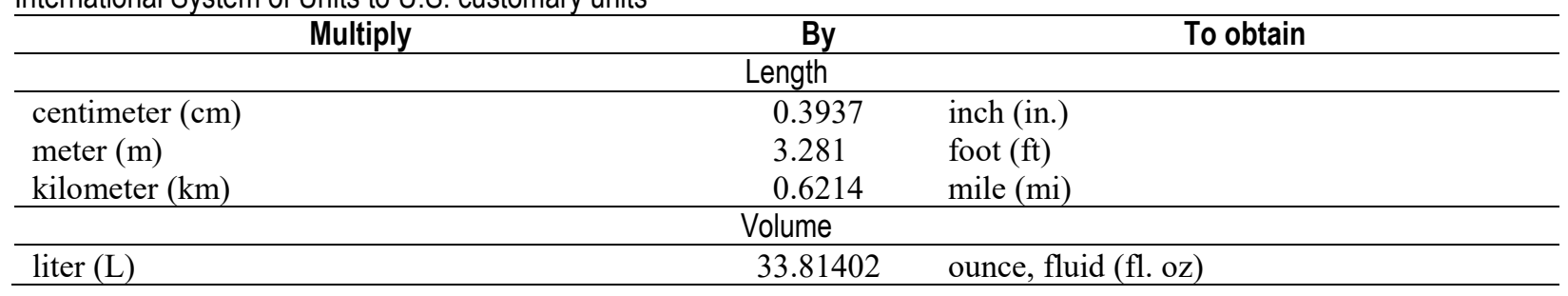

Temperature in degrees Celsius $\left({ }^{\circ} \mathrm{C}\right)$ may be converted to degrees Fahrenheit $\left({ }^{\circ} \mathrm{F}\right)$ as follows:

$$
{ }^{\circ} \mathrm{F}=\left(1.8 \times{ }^{\circ} \mathrm{C}\right)+32 \text {. }
$$

\section{Datum}

Vertical coordinate information is referenced to the North American Vertical Datum of 1988 (NAVD 88).

Elevation, as used in this report, refers to distance above the vertical datum.

\section{Abbreviations}

$\begin{array}{ll}\text { CJS } & \text { Cormack-Jolly-Seber } \\ \text { Ecology } & \text { Washington State Department of Ecology } \\ \text { Integrated Plan } & \text { Yakima Basin Integrated Plan } \\ \text { OLAFT } & \text { Off-ladder Adult Fish Trap } \\ \text { PIT } & \text { passive integrated transponder } \\ \text { RAMF } & \text { Roza Adult Monitoring Facility } \\ \text { Reclamation } & \text { Bureau of Reclamation } \\ \text { rkm } & \text { river kilometer } \\ \text { WFTS } & \text { Whooshh Fish Transport System }\end{array}$


This page left intentionally blank 


\section{Evaluation of Sockeye Salmon after Passage through an Innovative Upstream Fish-Passage System at Cle Elum Dam, Washington, 2017}

By Tobias J. Kock, Scott D. Evans, Amy C. Hansen, Russell W. Perry, Hal C. Hansel, Philip V. Haner, and Ryan G. Tomka

\section{Executive Summary}

The Bureau of Reclamation (Reclamation) and the Washington State Department of Ecology (Ecology), working with the Yakima River Basin Water Enhancement Project Workgroup (composed of representatives of the Yakama Nation; Federal, State, county, and city governments; environmental organizations; and irrigation districts), developed the Yakima Basin Integrated Plan (Integrated Plan). The Integrated Plan identifies a comprehensive approach to water resources and ecosystem restoration improvements in the Yakima Basin to be implemented over a 30-year period. The Integrated Plan includes seven elements:

1. Reservoir fish passage,

2. Structural and operational changes to existing facilities,

3. Surface water storage

4. Groundwater storage,

5. Habitat/watershed protection and enhancement,

6. Enhanced water conservation, and

7. Market reallocation.

The first listed element, reservoir fish passage, will be expensive and take many years to accomplish. Reclamation and Ecology decided to look at new and innovative means to provide passage that could help reduce project cost and construction timing while maintaining survival rates of traditional upstream passage facilities. Reclamation contracted with the U.S. Geological Survey to do a study to evaluate the outcome of passage through one innovative fish-passage system at Cle Elum Dam, the first Integrated Plan reservoir fish-passage project being implemented.

A study was completed in 2017 to evaluate the behavior and survival of adult sockeye salmon (Oncorhynchus nerka) after passage through the innovative Whooshh Fish Transport System (WFTS) at Cle Elum Dam, Washington. The study originally was designed to include the tagging and release of sockeye salmon adults from two sources:

1. Roza Dam. Three hundred fish were to be collected at Roza Dam, Washington, and tagged with a radio transmitter and passive integrated transponder (PIT) tag.

2. Priest Rapids Dam. Five hundred fish were to be collected at Priest Rapids Dam on the Columbia River, Washington, and tagged with a PIT tag. 
Sockeye salmon collected at Roza Dam are considered to originate in the Yakima River because they are progeny of fish collected at Priest Rapids Dam and released in Cle Elum Reservoir to reintroduce sockeye salmon in the Yakima Basin. The fish collected at Priest Rapids Dam are considered to originate in the Wenatchee and Okanogan Rivers. The original study design was modified, however, because the number of fish that returned to Roza Dam in 2017 was too low to support the needs of the study. Therefore, the evaluation proceeded using sockeye salmon that were collected only at Priest Rapids Dam.

Study fish collected at Priest Rapids Dam were transported to Roza Dam, where they were tagged with a radio transmitter and PIT tag. These fish were then transported to Cle Elum Reservoir for release at two locations. The first location was a holding tank near the WFTS entrance, in the tailrace of Cle Elum Dam. At that site, tagged fish either volitionally entered the WFTS or were netted and hand-loaded into the system. The WFTS included a transport tube that was 518 meters long and passed fish from the tailrace to the forebay of Cle Elum Dam, where they entered the reservoir. The second release site was located along the shoreline of Cle Elum Reservoir, 8.8 river kilometers ( $\mathrm{rkm})$ upstream of the dam. At that site, tagged fish were released directly into the reservoir from a fish transport truck. The original tagging and release plan included releases of fish for several weeks as Yakima River-origin fish moved upstream and arrived at Roza Dam. The revised tagging and release effort was shortened substantially compared to the original plan and occurred on a limited number of days in July 2017.

A total of 232 adult sockeye salmon were tagged and released during the study. Most tagged fish were passed through the WFTS (115 fish) or released at the reservoir release site (112 fish). The remaining five fish were either released directly into the tailrace of Cle Elum Dam (1 fish) or into the forebay of Roza Dam (4 fish). The fish that was released into the Cle Elum Dam tailrace was intended for WFTS passage, but was accidentally released when fish were being hand-fed into the WFTS. The fish released into the Roza Dam forebay were monitored to describe upstream movement patterns to Cle Elum Dam. All study fish were tagged on 1 of 5 days: July 14, 17, 18, 19, and 31, 2017.

Tagged fish were monitored from the time of release in July through late-November, when spawning was complete. Detection data were analyzed to describe behavior patterns of tagged fish and to estimate survival from the time of reservoir entry to September 1, 2017, which we defined as the start of the spawning period. Survival estimates were obtained for groups of fish passed through the WFTS and released at the reservoir release site (single-release estimates). These estimates were then used to calculate a survival estimate for WFTS passage survival (paired-release estimate). Overall, WFTS-passed and reservoir-released fish were comprised of similar proportions of Wenatchee Riverand Okanogan River-origin sockeye salmon. Fish size (fork length) also was similar between groups. The primary difference between the release site groups was that reservoir-released fish entered the reservoir $8.8 \mathrm{rkm}$ upstream of Cle Elum Dam on the same day they were collected and tagged, about the same time that WFTS-passed fish were released into the holding gallery where they could volitionally enter the WFTS. The holding gallery was continuously supplied with Cle Elum Dam tailrace water that was substantially colder (about 9 degrees Celsius $\left[{ }^{\circ} \mathrm{C}\right]$ ) than the temperature of the near-surface reservoir water (about $18^{\circ} \mathrm{C}$ ) that reservoir-released fish were initially exposed to. Although the WFTS-passed fish had continuous opportunity to exit the holding gallery by swimming over a false weir to enter the WFTS for fish passage, most failed to do so. Therefore, most WFTSpassed fish required hand-netting and manual loading into the WFTS for fish passage after spending about $20 \mathrm{~h}$ in the cool holding gallery water. The result was that most of the WFTS-passed fish entered the reservoir 1 day (d) after collection and tagging, a day later than the reservoir-released fish, having experienced the additional stress-associated factors of temperature, containment, and handling. 
Results indicate that tagged sockeye salmon that traveled through the WFTS initially sustained substantial mortality, but survival improved as the release period progressed and system adjustments were made. Single-release survival probability estimates for WFTS-passed fish were low (0.362) on the first release day and increased to a high of 0.749 on the last release day. In comparison, survival probability estimates for reservoir-released fish ranged from 0.853 to 1.000 on the four release days. Paired-release WFTS passage survival estimates ranged from 0.400 on the first release day to 0.795 on the last release day. Several factors were identified as likely contributors to the observed mortality. The WFTS fish-passage settings were calibrated and modified across release days to optimize fishpassage conditions. The opportunity to calibrate and optimize those settings prior to the start of the study was severely limited because of the small number of adult sockeye salmon that were available for the project. The original plan included the allocation of 50 untagged fish for system testing and calibration prior to the initiation of the study. However, only 13 fish were available for testing and calibrating the system. The WFTS was designed to include a misting system to provide lubrication to facilitate the glide through the WFTS tube for safe passage. On the third release day, Whooshh staff discovered a manufacturing defect that resulted in an inoperable misting system. Thus, there was insufficient misting for lubrication during fish passage of the outplanted fish during the first three release days. In addition to these factors, we determined that survival of WFTS-passed fish increased with increasing fish size. Each WFTS tube has an optimal fish size range specification for safe, effective, timely and efficient fish passage. For this project, a single tube size was available and all WFTS-passed fish were put through that tube. The observations described here provide insight into factors that may have contributed to the mortality of WFTS-passed fish during this study.

A substantial number of tagged sockeye salmon moved downstream of Cle Elum Reservoir and passed Cle Elum Dam. This behavior, termed fallback, was observed for about 20 percent of the tagged population and did not differ between groups of fish released through the WFTS or at the reservoir release site. Fallback by tagged fish at Cle Elum Dam primarily occurred within $40 \mathrm{~d}$ of release, and most (69 percent) of the tagged sockeye salmon that moved downstream of Cle Elum Dam remained in the Cle Elum River mouth-to-Cle Elum Dam reach. The remaining fish were last detected in the Roza Dam-to-Cle Elum River mouth reach (20 percent); downstream of Roza Dam (7 percent); or in the Yakima River, upstream of the Cle Elum River mouth (4 percent).

Upstream movement from Cle Elum Reservoir into the Cle Elum River was monitored to better understand movement patterns of tagged fish released in the reservoir. River entry primarily occurred during three peak periods. A substantial number of tagged sockeye salmon moved upstream and entered the Cle Elum River within $20 \mathrm{~d}$ of release, and this pattern was evident regardless of release location or origin. Most of these fish returned to the reservoir shortly after river entry and later indicated various movement patterns. The remaining periods of peak river entry occurred in September and again in October. Tagged fish generally appeared to show a short-term pattern of exploratory movement shortly after release. This exploratory movement was characterized by high rates of upstream movement into the Cle Elum River and fallback over Cle Elum Dam that occurred within 20 d of outplanting. Fish that remained upstream of Cle Elum Dam after this period showed limited movement in August and then resumed activity, primarily as upstream migration into the Cle Elum River during September-November.

Data were analyzed to assign fish to one of four possible fates during the spawning period: (1) mortality, (2) fallback, (3) reservoir, and (4) river. These fates were selected to provide insight into the proportion of outplanted fish that survived and remained upstream of Cle Elum Dam at the onset of the spawning period. The proportions of non-spawning fish (sum of mortality and fallback fates) were 29.4 and 57.4 percent for fish released directly into the reservoir and through the WFTS, respectively. The remaining tagged fish primarily were assigned to the river fate during the spawning period, as reservoir fates were very low (less than 5 percent). 
The four tagged fish released into the Roza Dam forebay showed limited movement. One of four moved upstream of Roza Dam and arrived in the tailrace of Cle Elum Dam. The other three fish initially moved upstream but failed to arrive at the mouth of the Cle Elum River. The lone fish that was accidentally released into the Cle Elum Dam tailrace did not leave that location.

\section{Introduction}

Sockeye salmon (Oncorhynchus nerka) historically were present in the Yakima Basin, Washington, but the population was eliminated in the early 1900s when several impassable dams were constructed (Bureau of Reclamation, 2007). These dams blocked access to four lakes in the Yakima Basin (Bumping, Keechelus, Kachess, and Cle Elum Lakes), which provided important spawning and rearing habitat for anadromous fish. As a result, sockeye salmon had been absent from the basin for nearly a century. In 2002, as part of a settlement agreement with the Yakama Nation, the Bureau of Reclamation (Reclamation) agreed to evaluate the feasibility of constructing fish-passage structures at the five reservoir dams in the Yakima Basin, eventually determining that this was feasible (Bureau of Reclamation, 2005, 2008). After the feasibility determination, Cle Elum Dam was selected to be the first site where passage facilities were constructed. The Yakama Nation and Washington Department of Fish and Wildlife then began planning efforts to reintroduce sockeye salmon into the Yakima Basin and in 2009, the Yakama Nation began releasing adult sockeye salmon into Cle Elum Reservoir. The initial reintroduction effort consisted of outplanting 1,000 adult sockeye salmon in the reservoir (Cle Elum) where they could spawn along shorelines or move upstream into the Cle Elum River (fig. 1). Outplanted fish were collected for translocation at Priest Rapids Dam on the main-stem Columbia River and originally were destined for either the Wenatchee or Okanogan Rivers (Galbreath and others, 2016; Matala and others, 2016). Monitoring efforts indicated that outplanted adults could successfully spawn upstream of Cle Elum Dam and produce progeny that eventually migrated to the ocean (Brian Saluskin, Yakama Nation, oral commun., 2017). Based on this success, annual outplanting efforts have continued since 2009, and in some years as many as 10,000 adult sockeye salmon collected at Priest Rapids Dam have been released into the reservoir. Releases now include fish from three origins: (1) Wenatchee River and (2) Okanogan River sockeye salmon from Priest Rapids Dam; and (3) Yakima River sockeye salmon collected at Roza Dam (fig. 1). The latter fish (3) are the progeny of sockeye salmon that spawned naturally, after outplanting, in the Cle Elum River system.

In 2012, the Yakima Basin Integrated Plan (Integrated Plan) was completed by the Yakima River Basin Water Enhancement Project Workgroup (composed of representatives of the Yakama Nation; Federal, State, county, and city governments; environmental organizations; and irrigation districts). The Integrated Plan identifies a comprehensive approach to water resource and ecosystem restoration improvements in the Yakima Basin to be implemented over 30 years (Bureau of Reclamation and Washington State Department of Ecology, 2012). The Integrated Plan includes seven elements:

1. Reservoir fish passage,

2. Structural and operational changes to existing facilities,

3. Surface water storage,

4. Groundwater storage,

5. Habitat/watershed protection and enhancement,

6. Enhanced water conservation, and

7. Market reallocation. 


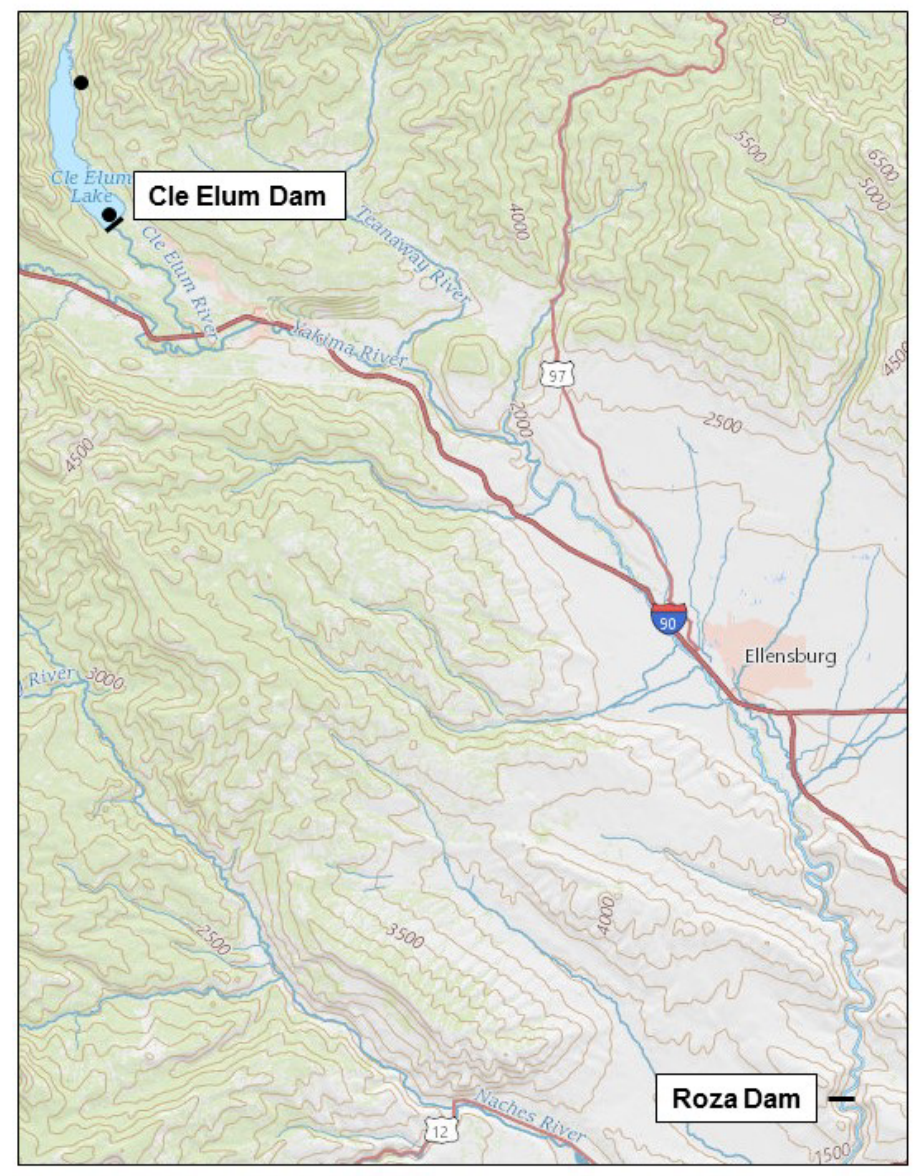

Figure 1. Locations of Roza Dam on the Yakima River, and Cle Elum Dam on the Cle Elum River, a tributary of the Yakima River, Washington. Black bars indicate dams, and filled circles indicate where adult sockeye salmon entered Cle Elum Reservoir (shown as Cle Elum Lake in figure) after passing through a Whooshh Fish Transport System at Cle Elum Dam or being released from a fish transport truck upstream of the dam.

The first listed element, reservoir fish passage, was projected to be expensive and to take many years to accomplish. Reclamation and the Washington State Department of Ecology (Ecology) decided to examine new and innovative means to provide upstream fish passage that could help reduce project cost and construction timing while maintaining survival rates of traditional upstream passage facilities. Reclamation contracted with the U.S. Geological Survey to do a study to evaluate fish after passage through one innovative fish-passage system at Cle Elum Dam, the first Integrated Plan fish-passage project being implemented.

An innovative fish-passage option that has emerged in recent years is the Whooshh Fish Transport System (WFTS; https://www.whooshh.com/). The WFTS consists of a soft, flexible tube and supporting structure that passes fish using differential air pressure created by the system. The WFTS was initially evaluated in 2011 with rainbow trout that were passed through a 15 -m-long tube (Mesa and others, 2013). The study authors determined that fish were not stressed or injured while passing through the system, and concluded that "it may allow for the rapid and safe movement of fish at hatcheries, sorting or handling facilities, or passage obstacles" (Mesa and others, 2013, p. 1179). 
Subsequent studies evaluated passage of various fish species, including American shad (Alosa sapidissima), pink salmon (O. gorbuscha), Chinook salmon (O. tshawytscha), lake sturgeon (Acipenser fulvescens), sockeye salmon (O. nerka), steelhead (O. mykiss), and Atlantic salmon (Salmo salar) with transport distances (tube length) as great as $335 \mathrm{~m}$ (Geist and others, 2014, 2016; Erikson and others, 2016; Fast and others, 2016; Fryer, 2017). These studies all noted that the WFTS provided safe and efficient passage for fish, which has led to increased interest in testing the system as a viable passage option at a high-head dam. Based on these results, and the need to provide upstream fish passage at Cle Elum Dam, Reclamation decided to evaluate the feasibility of using a WFTS at the project in 2017. To do this, they contracted with Whooshh Innovations to install and operate a 518-mlong, 55-m-high WFTS to pass adult sockeye salmon.

A study design was developed to evaluate the behavior and survival of adult sockeye salmon that passed through the WFTS at Cle Elum Dam. The original design was for 300 Yakima River-origin sockeye salmon to be collected at Roza Dam, radio- and PIT tagged, and released at three locations. The first release location was immediately upstream of Roza Dam, which would provide data on upstream fish movements to the Cle Elum Dam tailrace. The study design included the installation of a guidance net directing migrating tagged fish that arrived in the tailrace to the entrance of a Denil steeppass fishway leading to the fish holding tank (hereinafter, "holding gallery"; fig. 2). Data would be collected at the steep-pass to describe volitional entry rates from the river into the system. The second release site was a 24.4-m fish pipe that transported trucked fish to the holding gallery, located between the steep-pass fishway and the false weir entry of the WFTS. The holding gallery was a project requirement for the second release site and not a standard component of the WFTS. This release site would guarantee that sufficient numbers of tagged fish would be available to pass through the WFTS to allow evaluation of behavior and survival patterns of fish following WFTS passage. The third release site was in Cle Elum Reservoir, 8.8 river kilometers (rkm) upstream of Cle Elum Dam. Tagged fish released at the reservoir site would serve as a no fish passage control for the study. An additional 500 adult sockeye salmon were to be collected at Priest Rapids Dam, PIT tagged, and released into the holding gallery (250 fish) and reservoir (250 fish). The number of Yakima River-origin sockeye salmon that returned to the Yakima Basin in the summer of 2017 was extremely low. There were insufficient numbers of fish to support (1) prior to study commencement of the calibration and full functional operation system checks of the WFTS installation, and (2) the tagging needs of the project study design. Therefore, the study design was altered. We eliminated plans to tag and release Yakima River-origin fish and focused efforts on the planned releases of sockeye salmon collected at Priest Rapids Dam by the Yakama Nation as part of the annual reintroduction program. Because these fish originated in the Wenatchee and Okanogan Rivers, they were unlikely to move upstream, if released above Roza Dam, to the Cle Elum Dam tailrace. Thus, the study design was modified to use just two release sites: (1) the holding gallery in the Cle Elum Dam tailrace where fish could enter the WFTS and pass over Cle Elum Dam and (2) the reservoir release site. This document presents the findings of the modified study design that was used to evaluate sockeye salmon survival after WFTS passage and post-release behavior patterns of adult sockeye salmon in Cle Elum Reservoir. 


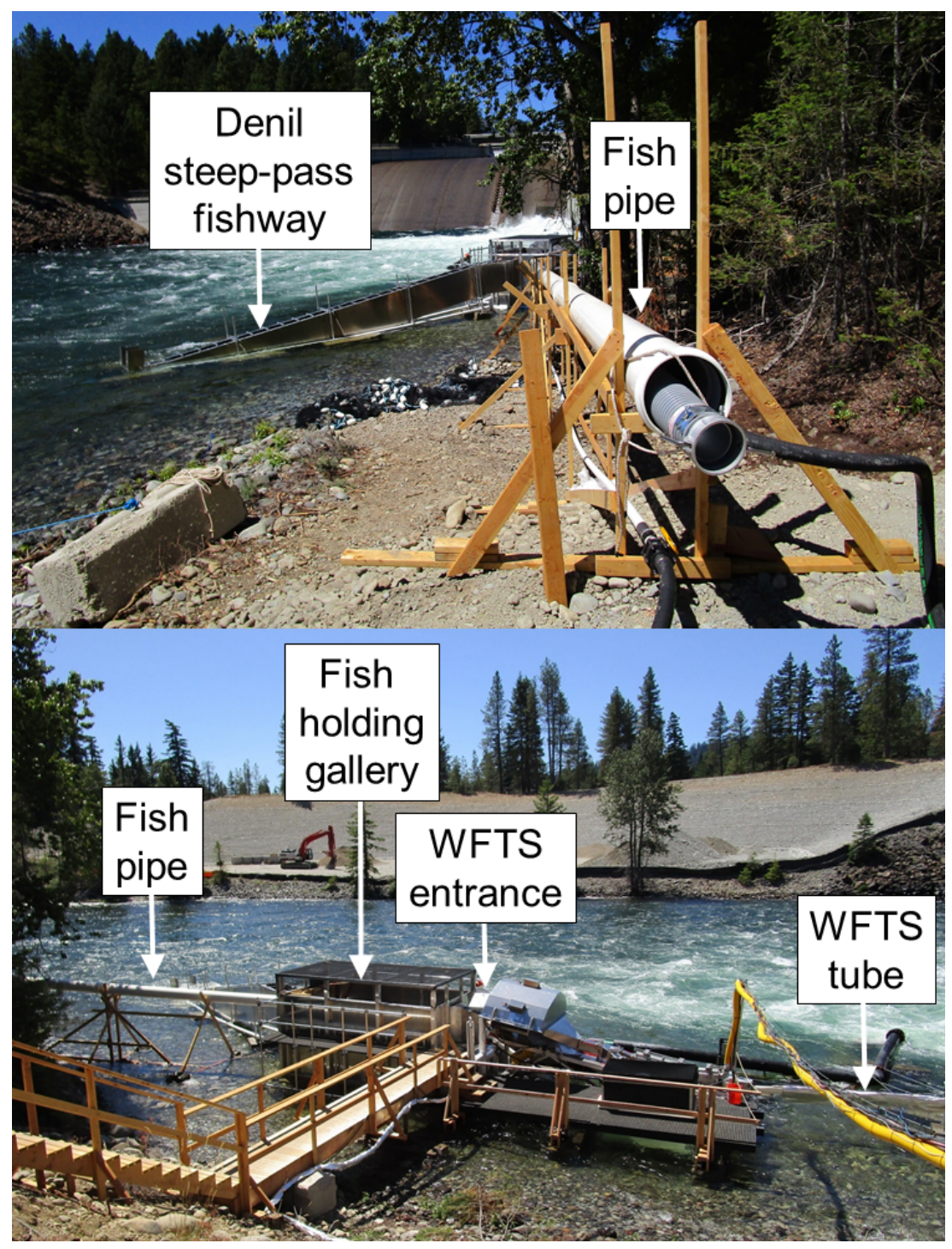

Figure 2. Components of the Whooshh Fish Transport System (WFTS) in the tailrace of Cle Elum Dam, Washington, 2017. Photographs by Tobias J. Kock, U.S. Geological Survey, July 14, 2017.

\section{Methods}

\section{Environmental Conditions}

Data were collected to describe water temperatures that study fish encountered during collection, tagging, and release. Water temperature at the time of collection was obtained as daily records from the forebay of Priest Rapids Dam for each date fish were collected for transport and tagging. These data were obtained from the Columbia River Data Access in Real Time web page (http://www.cbr.washington.edu/dart). Tagging temperature was obtained from a streamgage in the forebay of Roza Dam. These records were summarized as daily average values for each tagging date and were obtained from the Reclamation Yakima Project Hydromet System web page (https://www.usbr.gov/pn/hydromet/yakima). Release temperature data were collected separately for each release site. For fish released through the WFTS, we obtained daily temperature data in the 
WFTS holding gallery as measured by WFTS staff. For reservoir-released fish, we used data collected from a thermal temperature string that we deployed on the WFTS barge in the Cle Elum Dam forebay. The thermal string was deployed vertically from the barge and included eight temperature loggers that collected water temperature data at 5-min intervals. Loggers were deployed 2.4, 4.9, 7.3, 9.8, 12.2, 14.6, 17.1, and $18.9 \mathrm{~m}$ below the water surface. For water temperature at the time of release, we used the daily average from the logger located $2.4 \mathrm{~m}$ below the water surface. Data from all loggers also were summarized across the release period to provide information on temperature availability for tagged fish released through the WFTS. We did not use data from the loggers located at or lower than $14.6 \mathrm{~m}$ below the water surface after July 17 because receding water-surface elevations resulted in elimination of those depths. Water temperature data from fish transport trucks were not available.

Reservoir water elevation and discharge data were summarized for Cle Elum Reservoir and Cle Elum Dam, respectively. Daily data records were obtained from the Reclamation Yakima Project Hydromet System web page (https://www.usbr.gov/pn/hydromet/yakima) for July-November during each year from 2009 to 2017. These data were plotted separately as time-series summaries of annual conditions in the reservoir and at the dam during the period when sockeye salmon were present upstream of Cle Elum Dam. These data are presented in this report to enable visual comparative assessment of the 2017 conditions, relative to previous years.

\section{Fish Tagging and Release}

All but 4 of the 232 adult sockeye salmon that were tagged and released during the study period were collected at Priest Rapids Dam (rkm 639), on the Columbia River about 100 rkm upstream of the confluence with the Yakima River. Four sockeye salmon were collected, tagged, and released at the Roza Adult Monitoring Facility (RAMF), adjacent to Roza Dam on the Yakima River, providing limited data on movements between Roza and Cle Elum Dams. All tagging occurred on five dates: July 14, July 17-19, and July 31, 2017. On each of the first 4 days, adult sockeye salmon (about 60 fish per day) were collected at the Priest Rapids Dam Off-ladder Adult Fish Trap (OLAFT) and transferred to a fish transport truck. Access issues prevented us from tagging fish at Priest Rapids Dam, so fish were hauled to the RAMF for tagging, a distance of 111 highway km with an approximate transport time of $90 \mathrm{~min}$. At the RAMF, fish were netted from the transport truck and placed in the holding vault. Afterwards, the fish were crowded into a tank where they were anesthetized in groups of about 10 fish per group. The anesthetic bath was created by mixing $416 \mathrm{~L}$ of fresh river water with buffered tricaine methanesulfonate at a concentration of 30-40 parts per million. Individual fish were removed from the anesthetic bath and the following data were collected in the following manner:

1. Sex was determined via ultrasound,

2. A fork length measurement was taken (in centimeters),

3. Fish were scanned for the presence of a PIT or coded-wire tag, and

4. A DNA sample was taken (small clip from the caudal fin).

Fish were then tagged with a PIT tag and a radio transmitter (model Pisces; Sigma Eight, Inc., Newmarket, Ontario). The radio transmitter was implanted gastrically using procedures described in Keefer and others (2004). Tagged fish were then placed in a recovery container filled with fresh river water until they regained equilibrium, and transferred by bucket to one of two fish-hauling trucks. One truck hauled fish to the tailrace of Cle Elum Dam, where they were transferred to the holding gallery by a 24.4-m-long fish pipe. These fish eventually were passed through the WFTS. The second truck hauled fish to the release site in Cle Elum Reservoir, $8.8 \mathrm{rkm}$ upstream of Cle Elum Dam. On each truck, fish were held in a 1,514-L fiberglass tank that contained river water continuously supplied with oxygen. Tagged fish were loaded in a given truck until the quota for that day was met (25-32 fish), and then the next truck was loaded. On the first and third tagging days, tagged fish were first loaded 
onto the reservoir release truck and then the WFTS truck. This order was reversed on the second and fourth tagging days. The distance between Roza and Cle Elum dams is 79 highway km, with an approximate transport time of $60 \mathrm{~min}$. On July 17 and July 31, two adult sockeye salmon were collected each day after ascending the adult fish ladder at Roza Dam, and, thus, were available for tagging. These fish were tagged, but rather than being transported with the fish from OLAFT, they were released into the Roza Dam forebay to evaluate upstream movement to Cle Elum Dam.

The WFTS-passed and reservoir-released fish were subject to similar handling and transport events until the time of release. During and after release, the WFTS-passed fish required a series of handling steps that were not required for fish at the reservoir release site. Tagged fish arrived at the release sites in the early afternoon hours of each tagging day. At the Cle Elum Dam tailrace, the fish transport truck was positioned so that it could be directly attached to the polyvinyl chloride fish pipe connected to the holding gallery (fig. 2). Fish were transferred from the truck to the holding gallery through the fish pipe with the aid of streaming water. In the holding gallery, fish could volitionally pass over a false weir and enter the WFTS by sliding through to the WFTS tube to glide over Cle Elum Dam. The total length of the WFTS tube was $518 \mathrm{~m}$, and the anticipated transport time through a tube of this length was about 1 min (Janine Bryan, Whooshh Innovations, LLC, oral commun., 2017). The tube exit was located on the forebay exit barge anchored about $91 \mathrm{~m}$ upstream of Cle Elum Dam. Fish that did not volitionally pass over the false weir for WFTS passage within the first $24 \mathrm{~h}$ were netted from the holding gallery and hand-fed over the false weir to facilitate WFTS passage. To accommodate the project requirement to transport all tagged fish, regardless of size, the WFTS sizescanning system was deactivated during the study period. The system is designed to ensure fish size measurements are aligned with tube size specifications for safe fish passage. The deactivation of the system directed all sizes of tagged fish in the holding gallery to the WFTS tube for passage. The reservoir release site was located on the eastern shoreline of Cle Elum Reservoir, $8.8 \mathrm{~km}$ upstream of Cle Elum Dam (fig. 1). At that site, the transport truck was positioned at water's edge and fish were released directly into the reservoir through a hose that connected to the transport truck tank. All reservoir-released fish entered Cle Elum Reservoir on the day of collection and tagging, and received no further handling. Most of the WFTS-passed fish entered the reservoir the day following the day of collection and tagging, after netting and being hand-fed over the WFTS false weir.

\section{Fish Monitoring Array}

A total of 15 monitoring sites were established to detect tagged fish moving within the study area. All monitoring sites contained radiotelemetry equipment, except for a site on the WFTS and a site at Cle Elum rkm 26.0, which contained PIT tag monitoring equipment. Six sites were downstream of Cle Elum Dam (fig. 3). Two of these sites were located on Roza Dam-one site monitored the tailrace of the dam (Yakima rkm 205.7) and the other site monitored the forebay (Yakima rkm 205.8). A third site was located at the Cle Elum Hatchery (Yakima rkm 297.2). The remaining downstream sites were located in the tailrace of Cle Elum Dam (Cle Elum rkm 12.7) - one site monitored the Cle Elum River to detect fish in the tailrace; a second site monitored the WFTS holding gallery to determine residence time of tagged fish at that location; and a third site with a PIT tag monitoring antenna was located within the WFTS, immediately downstream of the entry point to the WFTS tube. 
Nine monitoring sites were located upstream of Cle Elum Dam (fig. 3). The first site was on Cle Elum Dam (Cle Elum rkm 13.2); five sites were positioned along the length of the reservoir on the western (Cle Elum rkm 15.9, 20.1, and 23.7) and eastern (Cle Elum rkm 20.1 and 22.5) shorelines; and three sites were in the Cle Elum River, upstream of the reservoir (Cle Elum rkm 25.6, 26.0, and 31.3).

Radiotelemetry monitoring sites were operated continuously from July 14 to November 11, 2017. The PIT tag monitoring site operated continuously from August 17 to October 20, 2017.

Mobile tracking was done weekly to collect additional information on the locations of tagged fish in the study area. During the early part of the study period (mid-July to mid-September), mobile tracking was done 1 or 2 days each week with efforts focused throughout the study area. During this period, a vehicle primarily was used for mobile tracking to cover as much area as possible. During the spawning period (September to November), mobile tracking occurred weekly, with efforts focused near the head of Cle Elum Reservoir and upstream in the Cle Elum River. The goals of these efforts were to (1) identify fine-scale locations of tagged individuals, (2) try to determine their fates (alive or dead), and (3) recover transmitters from dead fish. During this period, mobile tracking was done on foot primarily from Cle Elum rkm 22.5 to 31.3 .
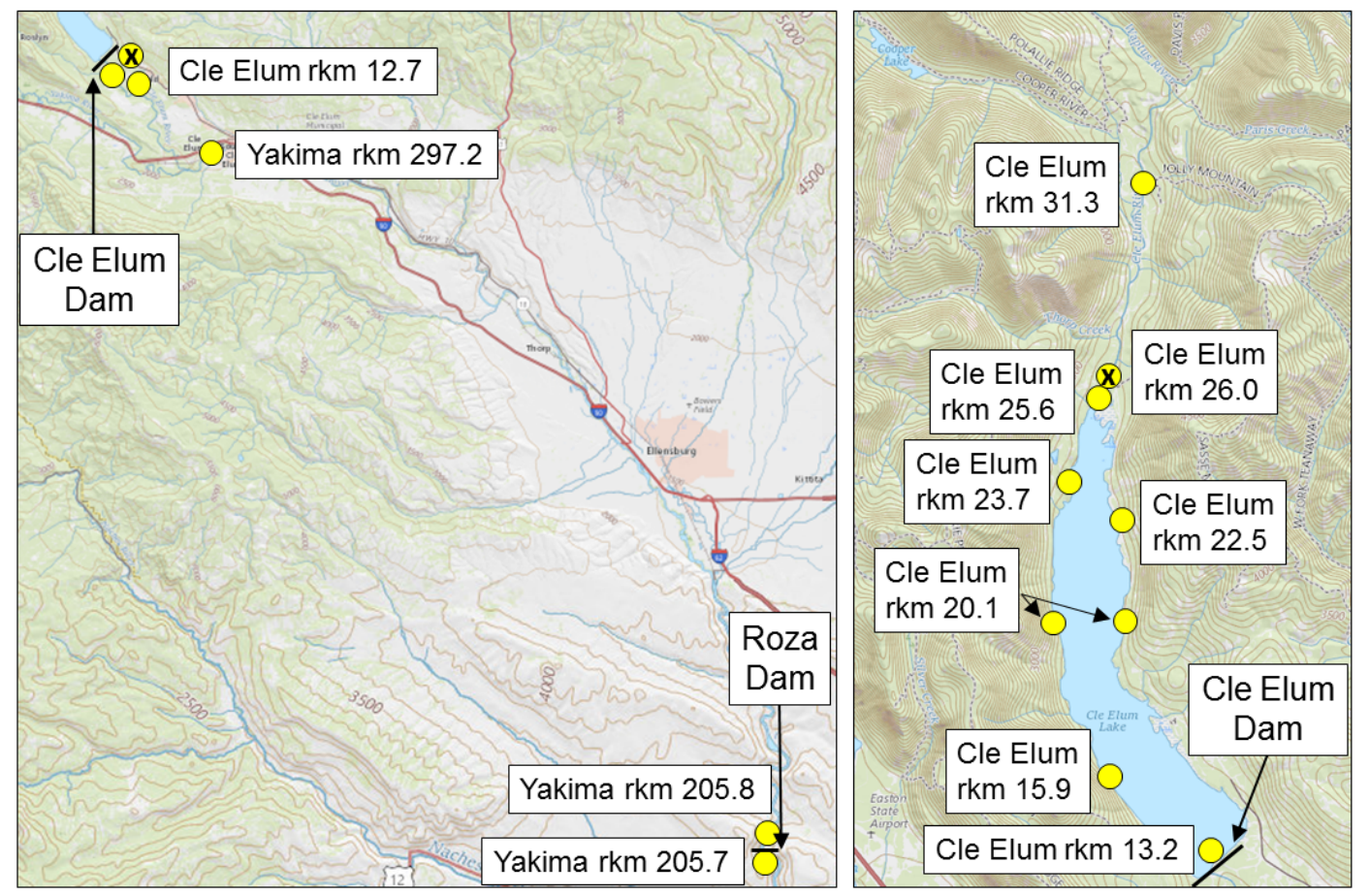

Figure 3. Locations of monitoring sites (yellow circles) used to detect tagged fish in the reach between Roza and Cle Elum Dams (left schematic), and in Cle Elum Reservoir and Cle Elum River upstream of the reservoir (right schematic), Washington. All sites are radiotelemetry sites except for sites marked with an "x", which are passive integrated transponder-tag monitoring sites. 


\section{Data Analysis}

The initial step in data analysis was to construct a comprehensive preliminary dataset assembled from information collected from multiple sources. Detection records from radiotelemetry and PIT tag monitoring sites were merged with tagging and release records to create the preliminary dataset. Results from genetic stock identification analysis of study fish done by the Columbia River Inter-Tribal Fish Commission were added to the dataset as well. Additionally, numerous reports were received of tag recoveries from the general public and fishery professionals who discovered tags and (or) carcasses in the field. This information provided important data on the fate of some tagged fish. These records were integrated in the preliminary dataset along with all mobile tracking records to create a draft dataset that was proofed using an automated program to remove non-valid detection records. Records were determined to be non-valid if:

1. They occurred prior to release,

2. The signal strength was less than the 90th percentile of the signal strength of detections of tag identification codes that were not released during the study (noise),

3. There were less than three consecutive detections,

4. They occurred after a tag was recovered, and

5. It was impossible for the detection to occur geographically (for example, detection in the tailrace after fallback followed by detection upstream of the dam).

These criteria are used in the automated program to remove non-valid detection records from the dataset containing actual detections of study fish. The auto-proofed dataset was then manually reviewed to confirm that the autoproofing process was successful and to verify that the dataset could be considered final for analysis. Survival and behavioral data analyses were subsequently done using the final dataset.

\section{Fish Survival}

A Cormack-Jolly-Seber (CJS; Cormack, 1964; Jolly, 1965; Seber, 1965) mark-recapture model with a paired-release design (Burnham and others, 1987) was used to estimate survival of radio-tagged adult sockeye salmon in this study. To apply the CJS models, telemetry detection records for each tagged fish were summarized in a three-digit capture history. A capture history is a string of digits (" 0 " $=$ not detected, "1" = detected) that summarize the detection history of each fish. The first digit represented release into the study area, so all fish received a " 1 " for this position in the capture history. The second digit represented fish movement that occurred during the month of September. Sockeye salmon begin spawning upstream of Cle Elum Dam in September (Galbreath and others, 2016; Matala and others, 2016), so live fish would be expected to be moving (to locate spawning areas) during this period. Tagged fish were assumed to be alive and moving if they were detected at a minimum of two separate fixed sites during the month of September. Those fish received a " 1 " for the second digit in the capture history. Tagged fish with no evidence of movement between sites during this period received a " 0 ". The third digit represented evidence of fish movement that occurred during the months of October and November. Tagged fish that were detected at a minimum of two separate fixed sites during those months received a " 1 " and those that did not received a " 0 ". As an example, a fish with a capture history of "110" represented a fish that was released in July, was detected moving between two or more fixed sites in September, but not detected moving between a minimum of two fixed sites in October or November. Similarly, a capture history of "100" represented a fish that was released in July 
but not detected moving between at least two fixed sites after September 1. This capture history represented a detection history for a fish that failed to survive to the start of the spawning period. We assumed that the collection of fixed sites installed for this study were sufficiently located to detect and distinguish movement patterns of live, tagged sockeye salmon within the study area. We also assumed that tagged fish that regurgitated their transmitter prior to the start of the spawning period would receive a capture history of " 100 ".

The three-digit capture history allowed us to estimate three types of parameters using the CJS model: (1) S, survival from the time of release to the time of detection at a fixed site in September; (2) $p$, the probability of detection at fixed sites in September; and (3) $\lambda$, the joint probability of surviving from September to October-November and being detected at fixed sites in October-November. The CJS model was then fit to the capture history data to estimate (1) survival for each release site - that is, fish passed through the WFTS and fish released directly into Cle Elum Reservoir; (2) release group survival determined individually for each of the four release days; and (3) survival as a function of the fork length of each tagged fish. The modified study design altered the project such that adaptive calibrations and operational improvements were being implemented on the WFTS during the study period. Given these factors, the evaluation of survival by release day provided the opportunity to examine how these adaptations affected WFTS passage survival. Tagged fish were assigned to specific release days based on the date they were released into the holding gallery or released directly into the reservoir at the reservoir release site.

The two release sites also provided the opportunity to use a paired-release design to estimate relative differences in survival between WFTS-passed and reservoir-released fish. (Burnham and others, 1987; Skalski and others, 2001; Zydlewski and others, 2017). The paired-release approach uses two release groups, which effectively serve as treatment and controls in the study design. In this study, fish passed through the WFTS were the treatment group and fish released directly into the reservoir were the control group. The paired-release estimate of survival is calculated as the ratio of treatment to control group survival:

$$
S_{\mathrm{WTFS} \text { pass }}=\frac{S_{\mathrm{WTFS}}}{S_{\mathrm{Res}}},
$$

where $S_{\text {WTFS }} \quad$ is the Cormack-Jolly-Seber (CJS) estimate of unadjusted survival for the Whooshh Fish Transport System (WTFS) release site group (treatment),

$S_{\text {Res }} \quad$ is the CJS estimate of survival for the reservoir release site group (control), and

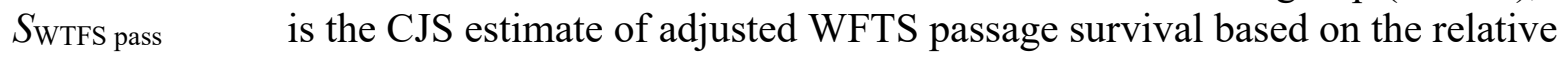
survival of control fish released directly into the reservoir on the same date.

The goal of the paired-release design is to control for factors common to both release groups, thereby isolating effects of the treatment on survival. In this study, CJS estimates of survival measure the combined effects of capture, transport, handling, and natural mortality between time of entry into the reservoir and time of detection in September. Because these factors are common to both release site groups, these effects are cancelled when the ratio of survival estimates is considered. Thus, if there were no effect of WFTS passage on survival, we would expect this ratio to be 1 to 1 . In contrast, differences between treatment and control groups that differentially influence survival, such as additional handling associated with WFTS and passage through the WFTS, are represented as a survival ratio of less than 1. Research by Matala and others (2016) has shown that fish size (age), spawn timing, and spawning distribution differ between fish of Wenatchee River origin and Okanogan River origin. To account for potential effects of origin, we assessed for proportional differences of the two fish stocks between each release group using a Chi-squared test. 
To complete the mark-recapture analysis, we used the RMark package in R (Laake, 2013), which facilitates running Program Mark (White and Burnham, 1999). The CJS model we developed included three covariates to assess factors that may have affected survival: (1) release day (Rdayi), (2) release site $\left(\mathrm{Rsite}_{i}\right)$, and (3) fork length $\left(\mathrm{FL}_{i}\right)$ of the $i$ th individual. In the survival analysis, release days 1-4 were associated with fish tagged on July 14, 17, 18, and 19, 2017, respectively. For inclusion in the analysis, fork length was standardized to mean 0 and unit standard deviation by subtracting its mean (mean $=49.8 \mathrm{~cm})$ and then dividing by the standard deviation $(4.2 \mathrm{~cm})$. Survival was modeled as a linear function of these covariates on the logit scale as follows:

$$
\operatorname{logit}\left(S_{i}\right)=\beta_{0, \text { day }_{i}, \text { Rsite }_{i}}+\beta_{1, \text { Rsite }_{i}} \mathrm{FL}_{i},
$$

where logit()

$\beta_{0, R \text { day }_{i}, \text { Rsite }_{i}}$

$\beta_{1, \text { Rsite }_{i}}$

is the logit function $(\log [\mathrm{x} /(1-\mathrm{x})])$,

is the intercept for each release site and release day, and

is the slope of the relationship between fork length and survival for each release site.

This model structure provided survival probability estimates for fish passed through the WFTS and at the reservoir release site for each release day. Other parameters in the model ( $p$ and $\lambda)$ were estimated as a common parameter across all release sites and release days.

One factor that could introduce bias into our estimation of fish survival was transmitter regurgitation. Research has shown that gastrically tagged fish can regurgitate their transmitter after release (Keefer and others, 2004). If this occurred in our study, bias would result as live fish that were no longer radio-tagged could move within the study area and not be detected, and, therefore, could be considered mortalities. To assess relative regurgitation rates, we compared detection events on the PIT tag and radiotelemetry sites upstream of Cle Elum Reservoir. We used the date and time of each PIT tag detection at Cle Elum rkm 26.0 to establish a 6-h period around that PIT tag detection event ( $3 \mathrm{~h}$ prior to the event, $3 \mathrm{~h}$ after the event). We then queried the radiotelemetry detection records to determine if the radio transmitter associated with the fish detected on a given PIT tag detection event was detected at sites located at Cle Elum rkm 25.6 or 31.3, or by mobile tracking within that reach. If the PIT tag and radio transmitter were both detected within the Cle Elum rkm 25.6-31.3 reach during the $6 \mathrm{~h}$ period, we assumed that the fish had not regurgitated the radio transmitter. If the PIT tag detection was not accompanied by a radio transmitter detection within the $6 \mathrm{~h}$ period in that reach, we examined all radio transmitter detections for that fish after the time of the PIT tag detection event. If radio transmitter detections were present on multiple sites, we assumed that the radio transmitter was still present inside the fish but had failed to be detected by radiotelemetry sites at the time of the PIT tag detection event. If no radio transmitter detections were present, or if radio transmitter detections were discovered on a single site only, we assumed that the radio transmitter had been regurgitated.

\section{Fish Behavior}

We examined the final dataset to describe the behavior of the four tagged fish released into the Roza Dam forebay. Travel time from Roza to Cle Elum Dams was calculated as the date and time of first detection in the Cle Elum Dam tailrace minus the date and time of release in the Roza Dam forebay. Given that the total number of tagged fish released at Roza Dam was small, information gleaned from these fish was expected to be useful but lacking in statistical rigor.

Several aspects of fish behavior of tagged fish released in Cle Elum Reservoir were examined, including (1) the percentage of fish that moved downstream past Cle Elum Dam (hereinafter, "fallback"); (2) the percentage of fish that moved upstream and entered the Cle Elum River; and (3) the fate of fish during the spawning period. We examined the effects of the release site (WFTS compared to the reservoir) for all analyses to determine if behavior differed between the groups of fish that passed through the WFTS and those released at the reservoir release site. 
Fallback was identified as detection of individual tagged fish downstream of Cle Elum Dam after release in Cle Elum Reservoir. For each tagged fish that moved downstream of Cle Elum Dam, we calculated the elapsed time to fallback by subtracting the date and time of first detection in the tailrace from the date and time of release in the reservoir. The percentage of fallback fish was calculated by dividing the total number of fish that fell back by the total number of fish released in Cle Elum Reservoir.

Reservoir water elevations changed throughout the study period, which altered the terrain and river definition. During July and August, Cle Elum Reservoir was full or nearly full, such that the reservoir/river boundary was located near our fixed site at Cle Elum rkm 25.6 (fig. 3). Thus, fish were considered to have entered the Cle Elum River in July and August 2017 when detected at, or upstream of Cle Elum rkm 25.6. Reservoir water elevations declined rapidly after August 2017, reducing the reach of the reservoir and extending the Cle Elum River several kilometers farther downstream before meeting the reservoir/river boundary, which was near our fixed site at Cle Elum rkm 22.5. River entry was assigned if tagged fish were detected at or upstream of Cle Elum rkm 22.5 during the SeptemberNovember 2017 spawning period. Upstream movement data were summarized to provide information on the number of trips each tagged fish made from the reservoir to the river. Maximum upstream movement by individual tagged fish also was determined as the farthest upstream detection observed for each tagged fish on fixed sites or by mobile tracking.

Several aspects of fish behavior were considered in the assignment of fate to the tagged outplanted individual fish during the spawning period. Each tagged fish that entered Cle Elum Reservoir was assigned to one of four possible fates: (1) mortality, (2) fallback, (3) reservoir, and (4) river. Fish were assigned a mortality fate as part of the fish survival analysis. All fish with a "100" capture history were considered to have a mortality fate, which was defined as the cessation of tag detection at a minimum of two fixed monitoring sites upstream of Cle Elum Dam prior to September 1, 2017, minus any fallback fish. Similarly, all fish that were detected downstream of Cle Elum Dam after reservoir entry, prior to September 1, 2017, were assigned to the fallback fate. The remaining fish were detected moving upstream of Cle Elum Dam during the spawning period (September-November 2017) and, therefore, had the opportunity to spawn in the reservoir or in the river. Tagged fish in this group that were never detected in the river were assigned to the reservoir fate. All remaining tagged fish were detected upstream of Cle Elum Reservoir during the spawning period and, therefore, were assigned the river fate.

\section{Results of Fish-Passage Device Evaluation}

\section{Environmental Conditions}

Sockeye salmon adults that were tagged for this study experienced a range of water temperatures on days when they were collected, tagged, and released. At the time of collection, water temperature in the Priest Rapids Dam forebay was near $18^{\circ} \mathrm{C}$ (table 1). The fish then traveled about 90 min by truck. When they arrived at Roza Dam for tagging, the daily average forebay water temperature was recorded at about $15^{\circ} \mathrm{C}$ (table 1). The tagged fish then traveled an additional $60 \mathrm{~min}$ in one of two trucks to the study release sites. The thermal experience of the tagged fish varied considerably at the release sites. Tagged fish released into the holding gallery entered water pumped from the dam tailrace, which was about $9{ }^{\circ} \mathrm{C}$. Most of the tagged fish at this site did not volitionally enter the WFTS for dam passage and, therefore, were confined to the cool water temperature in the holding gallery for about $20 \mathrm{~h}$ before handling was done to facilitate fish passage. In contrast, the reservoir-released fish entered reservoir water with recorded near-surface temperatures in the $18-19{ }^{\circ} \mathrm{C}$ range (table 1). These fish were immediately free to move throughout the reservoir. 
Data collected from the vertical temperature string located on the WFTS exit barge in the Cle Elum Dam forebay indicated that the near-surface water temperature was $18{ }^{\circ} \mathrm{C}$ or more during the release period (fig. 4). Water temperature at that site decreased with increasing depth to a low of about $13{ }^{\circ} \mathrm{C}$ at depths of $17.1 \mathrm{~m}$ or greater. Fluctuations in water temperature at each depth were moderate within the short release period (fig. 4).

Cle Elum Dam discharge and forebay water elevations in 2017 were representative of typical conditions during 2009-16 (fig 5.). Discharge from Cle Elum Dam was about 2,000 $\mathrm{ft}^{3} / \mathrm{s}$ in early July, peaked at about 3,500 $\mathrm{ft}^{3} / \mathrm{s}$ in early August, and then decreased to a fairly constant low of about 250 $\mathrm{ft}^{3} / \mathrm{s}$ after early September and maintained that rate through the spawning period (fig. 5). Reservoir water elevations were highest in early July (about 2,240 ft), declined to a low of about 2,150 ft in midOctober, and then increased slightly in November and December (fig. 5).

Table 1. Daily mean water temperature in the forebays of Priest Rapid and Roza Dams, in the holding gallery near the Whooshh Fish Transport System entrance, and in the forebay of Cle Elum Dam, when adult sockeye salmon were collected and tagged for an evaluation in Cle Elum Reservoir, Washington, July 2017.

[All values in table are daily mean water temperature in degrees Celsius. WFTS, Whooshh Fish Transport System; - , data not recorded]

\begin{tabular}{ccccc}
\hline Date & $\begin{array}{c}\text { Priest Rapids Dam } \\
\text { forebay }\end{array}$ & $\begin{array}{c}\text { Roza Dam } \\
\text { forebay }\end{array}$ & Holding gallery & $\begin{array}{c}\text { Cle Elum Dam } \\
\text { forebay }\end{array}$ \\
\hline July 14 & 18.4 & 15.5 & 8.9 & 18.5 \\
July 17 & 17.9 & 14.8 & - & 18.8 \\
July 18 & 18.4 & 15.5 & 9.2 & 18.7 \\
July 19 & 18.4 & 15.8 & 9.0 & 18.9 \\
\hline
\end{tabular}

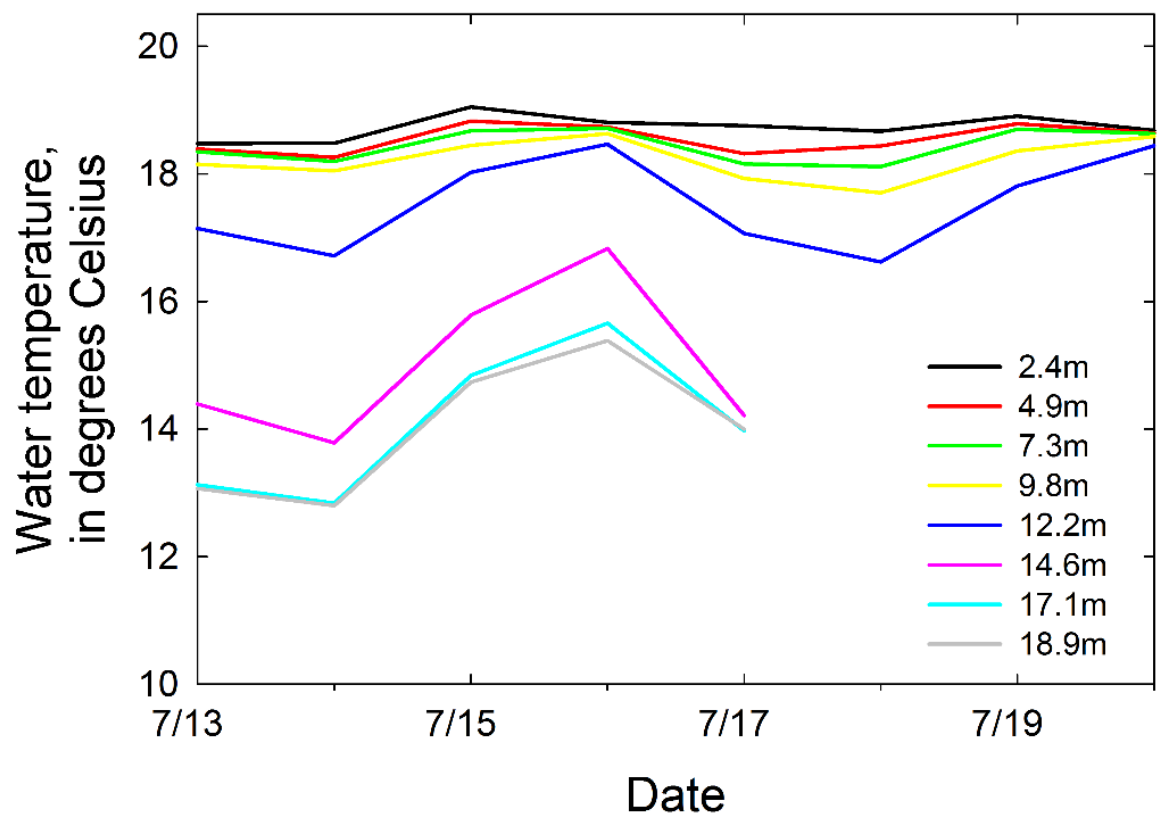

Figure 4. Daily average water temperature during the study release period at eight depths (in meters [m] below water surface) in the forebay of Cle Elum Dam, Washington, 2017. 


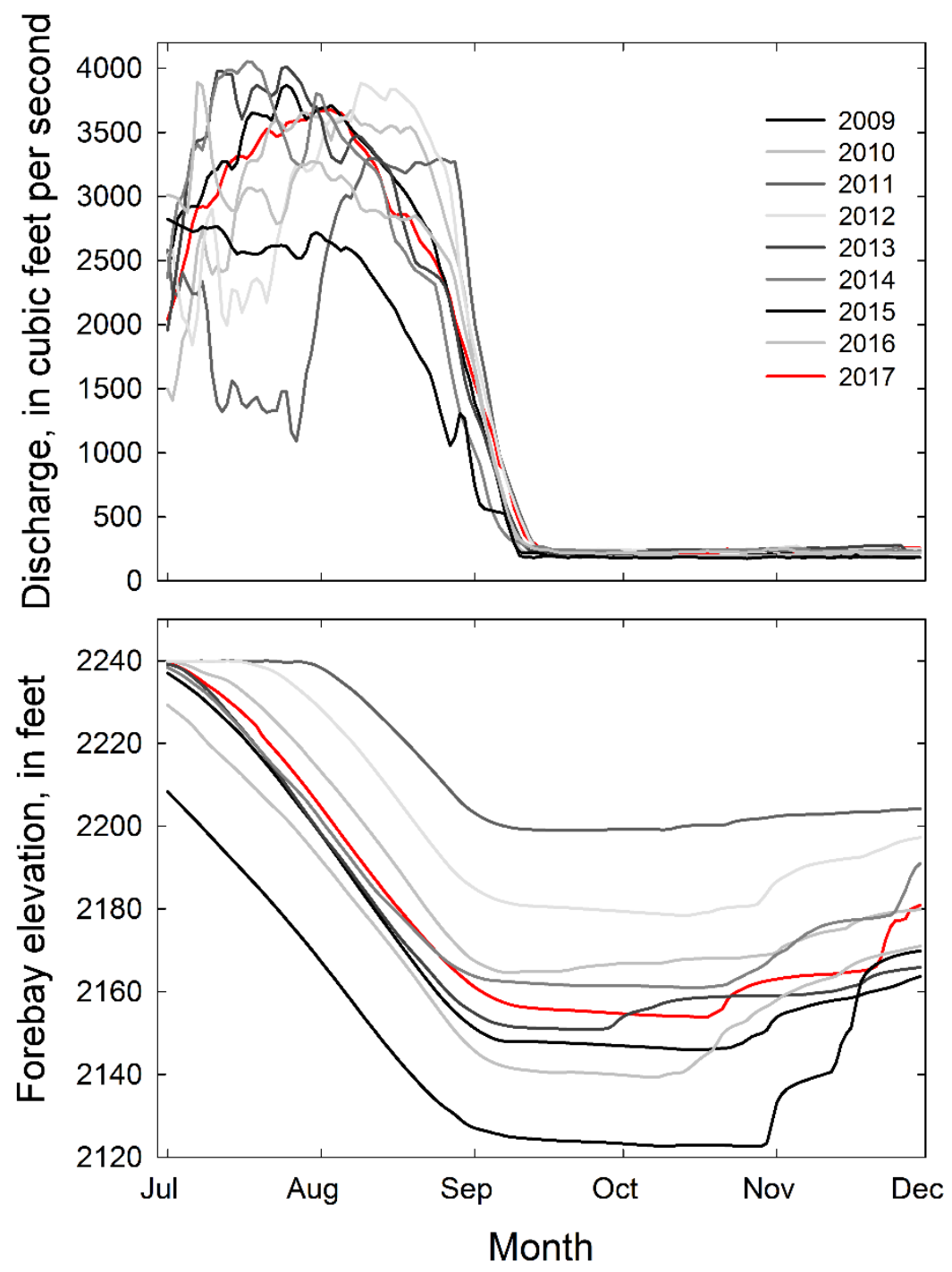

Figure 5. Daily discharge from (top graph) and forebay elevation of water surface level at (bottom graph) Cle Elum Dam, July-December 2009-17. 


\section{Fish Tagging and Release}

A total of 232 adult sockeye salmon were tagged and released during the study. Four fish were released in the Roza Dam forebay, and one fish was accidentally released in the Cle Elum Dam tailrace by WFTS staff while facilitating fish transfer into the WFTS (table 2). All remaining fish entered Cle Elum Reservoir, either by 518-m fish passage over the dam through the WFTS or by direct release from the transport truck at the reservoir release site (table 2). Daily releases at these two sites ranged from 25 to 32 fish (table 2).

Genetic analysis of tissue samples collected at the time of tagging showed that WFTS-passed and reservoir release groups were comprised of similar (Chi-squared test, $p=0.319$ ) proportions of Okanogan River- and Wenatchee River-origin sockeye salmon. A total of 115 adult sockeye salmon were passed through the WFTS. These included 61 (53 percent) Okanogan River-, and 54 (47 percent) Wenatchee River-origin fish (table 2). The reservoir release group consisted of a total of 112 adult sockeye salmon of which 52 (46 percent) were Okanogan River-origin and 60 (54 percent) were Wenatchee River-origin (table 2). The proportion of Okanogan River-origin and Wenatchee Riverorigin fish varied within groups by tagging date (table 2). Average fork length of Wenatchee Riverorigin sockeye salmon $(51.4 \mathrm{~cm})$ was greater than average fork length of Okanogan River-origin sockeye salmon $(47.9 \mathrm{~cm}$; t-test, $p<0.0001)$ that were tagged and released during the study. Average fork length of WFTS-passed sockeye salmon $(49.8 \mathrm{~cm})$ was not statistically different from average fork length of reservoir-released sockeye salmon (49.5 cm; t-test, $p=0.609)$.

Table 2. Number and origin of adult sockeye salmon tagged and released during the study at Roza and Cle Elum Dams, the Whooshh Fish Transport System, and Cle Elum Reservoir, Washington, July 2017.

[O, Okanogan River-origin; W, Wenatchee River-origin; WFTS, Whooshh Fish Transport System]

\begin{tabular}{|c|c|c|c|c|c|c|c|c|c|}
\hline \multirow{2}{*}{$\begin{array}{l}\text { Tagging } \\
\text { date }\end{array}$} & \multirow{2}{*}{$\begin{array}{l}\text { Tagging } \\
\text { day }\end{array}$} & \multicolumn{2}{|c|}{ Roza Dam release } & \multicolumn{2}{|c|}{$\begin{array}{c}\text { Cle Elum Dam } \\
\text { release }\end{array}$} & \multicolumn{2}{|c|}{ WFTS-passed } & \multicolumn{2}{|c|}{$\begin{array}{c}\text { Cle Elum Reservoi } \\
\text { release }\end{array}$} \\
\hline & & 0 & W & 0 & W & 0 & $\mathbf{W}$ & 0 & W \\
\hline July 14 & 1 & - & - & - & - & 9 & 16 & 13 & 12 \\
\hline July 17 & 2 & & ${ }^{1} 2$ & - & 1 & 14 & 13 & 13 & 14 \\
\hline July 18 & 3 & - & - & - & - & 21 & 11 & 11 & 19 \\
\hline July 19 & 4 & - & - & - & - & 17 & 14 & 15 & 15 \\
\hline July 31 & 5 & - & 2 & - & - & - & - & - & - \\
\hline \multicolumn{2}{|c|}{ Sub-total } & - & 2 & 0 & 1 & 61 & 54 & 52 & 60 \\
\hline \multicolumn{2}{|c|}{ Total } & \multicolumn{2}{|r|}{14} & & 1 & \multicolumn{2}{|c|}{115} & \multicolumn{2}{|c|}{112} \\
\hline
\end{tabular}

${ }^{1}$ Fish with unknown origin at the time of reporting. 


\section{Fish Survival}

Although 227 adult sockeye salmon were released into Cle Elum Reservoir, 19.8 percent moved downstream of Cle Elum Dam prior to spawning (see section, "Fallback at Cle Elum Dam") and, therefore, were not available for assessment of survival. The exclusion of fallback fish from the survival analysis resulted in a total of 182 tagged fish (94 in the WFTS-passage group; 88 in the reservoir-released group) available for survival analysis. Nearly one-half (48 percent) of the tagged adult sockeye salmon that passed through the WFTS and that remained upstream of Cle Elum Dam had a "100" capture history (that is, not detected at two or more fixed sites after September 1) compared to 10 percent of the reservoir-released fish (table 3). This indicates a survival difference between the groups of fish released at the two sites. Parameter estimates from the CJS model used to estimate survival are shown in table 4.

Single-release survival probability estimates for tagged fish passed through the WFTS were low (0.362) on the first release day and increased each day to 0.749 on the last release day (fig. 6). For reservoir-released fish, single-release survival probability estimates were 0.853 or greater on each release day (fig. 6). Paired-release survival probability estimates showed that WFTS passage survival was lowest (0.400) for fish from release day 1, increased to 0.602 and 0.569 on release days 2 and 3 , respectively, and was highest (0.795) on release day 4 (fig. 7). The effect of fork length on passage survival on release day 4 is shown for two groups of fish, those that passed through the WFTS and those released at the reservoir release site (fig. 8). The graph shows a positive relation between fork length and passage survival for WFTS-passed fish, which was not observed for reservoir-released fish (fig. 8).

A total of 84 tagged sockeye salmon were detected by PIT tag antennas at Cle Elum rkm 26.0 while that site was operational. Many fish were detected more than one time, resulting in a total of 166 PIT tag detection events. Most of these PIT tag detection events (133 detections; 80 percent) were associated with radio transmitter detections within the 6-h detection window used to assess transmitter regurgitation rates. The remaining 33 PIT tag detection events were from 24 tagged individuals. Eleven of the tagged fish were subsequently detected on multiple telemetry sites in the study area, indicating that they had not regurgitated their transmitter. The remaining 13 fish were last detected upstream of the PIT tag antenna, indicating that the transmitter had not been regurgitated at the time when each fish was detected moving upstream at Cle Elum rkm 26.0. Three of the transmitters from these fish were recovered from carcasses after spawning, further supporting this assumption.

Table 3. Summary of capture histories for adult tagged sockeye salmon passed into Cle Elum Reservoir through a Whooshh Fish Transport System (WFTS) or released at a shoreline release site (Reservoir), Washington, 2017.

[These numbers do not include tagged fish that moved downstream and passed Cle Elum Dam. 100: Fish that were released in July but not detected moving between at least two fixed sites after September 1. 101: Fish that were released in July, were not detected moving between two or more fixed sites in September, but were detected moving between a minimum of two fixed sites during October-November. 110: Fish that were released in July, were detected moving between two or more fixed sites in September, but not detected moving between a minimum of two fixed sites during October-November. 111: Fish that were released in July, were detected moving between two or more fixed sites in September, and then detected moving between a minimum of two fixed sites during October-November]

\begin{tabular}{|c|c|c|c|c|c|}
\hline \multirow{2}{*}{ Release site } & \multicolumn{4}{|c|}{ Capture history } & \multirow[b]{2}{*}{ Total } \\
\hline & 100 & 101 & 110 & 111 & \\
\hline WFTS & 45 & 2 & 24 & 23 & 94 \\
\hline Reservoir & 9 & 3 & 39 & 37 & 88 \\
\hline
\end{tabular}


Table 4. Parameter estimates from the Cormack-Jolly-Seber mark-recapture model used to estimate survival of tagged adult sockeye salmon released into Cle Elum Reservoir, Washington, 2017.

[Confidence interval for fish released at the reservoir release site on release day 3 was not estimable $(\mathrm{n} / \mathrm{a})$ because that group of fish had perfect survival. Parameter: $\beta_{0}$, intercept; $\beta_{1}$, slope. Group: Res, reservoir release group; WFTS, Whoosh Fish Transport System passage group; Rday, release day; FL, fork length; $p$, detection probability; $\lambda$, joint probability of surviving and being detected]

\begin{tabular}{llcc}
\hline \multicolumn{1}{c}{ Parameter } & Group & Estimate & 95-percent confidence interval \\
\hline & Res Rday1 & 2.254 & $0.401-4.107$ \\
& WFTS Rday 1 & -0.566 & $-1.540-0.408$ \\
& Res Rday 2 & 1.759 & $0.246-3.272$ \\
$\beta_{0}$ & WFTS Rday 2 & 0.055 & $-0.878-0.989$ \\
& Res Rday 3 & 1.000 & $\mathrm{n} / \mathrm{a}$ \\
& WFTS Rday 3 & 0.276 & $-0.644-1.196$ \\
& Res Rday 4 & 2.782 & $0.766-4.798$ \\
& WFTS Rday 4 & 1.093 & $0.100-2.086$ \\
& & & \\
& Res FL & 0.367 & $-0.598-1.331$ \\
& WFTS FL & 0.878 & $0.291-1.461$ \\
$\beta_{1}$ & $\operatorname{logit}(p)$ & 2.728 & $1.825-3.632$ \\
& $\operatorname{logit}(\lambda)$ & -2.744 & $-3.673-1.815$ \\
\hline
\end{tabular}

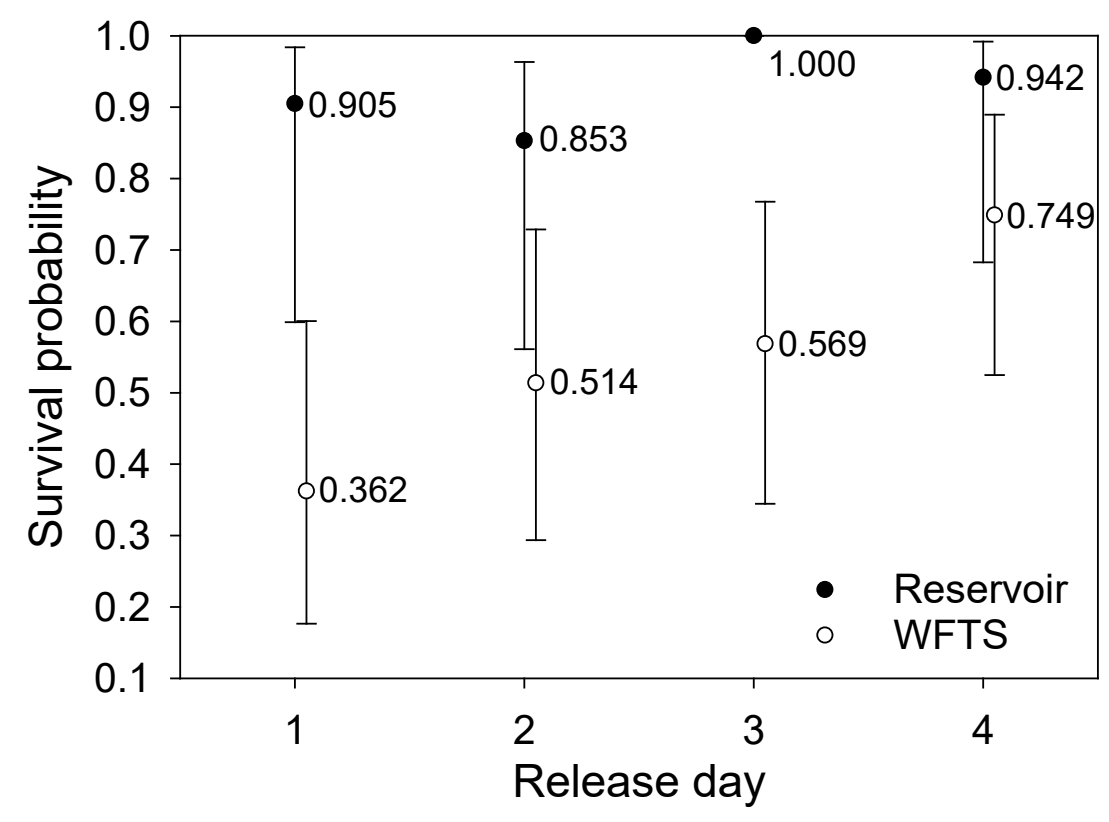

Figure 6. Estimates of Cormack-Jolly-Seber single-release survival probability ( $S_{W T F S}$ and $S_{\text {Res }}$ ) for adult sockeye salmon passed through a Whooshh Fish Transport System (WFTS) or released directly into Cle Elum Reservoir at a reservoir release site (Reservoir), Washington, July 14 (Release day 1) and July 17-19 (Release days 2-4), 2017. Estimates are for the mean sized (fork length) adult sockeye salmon tagged during this study. 


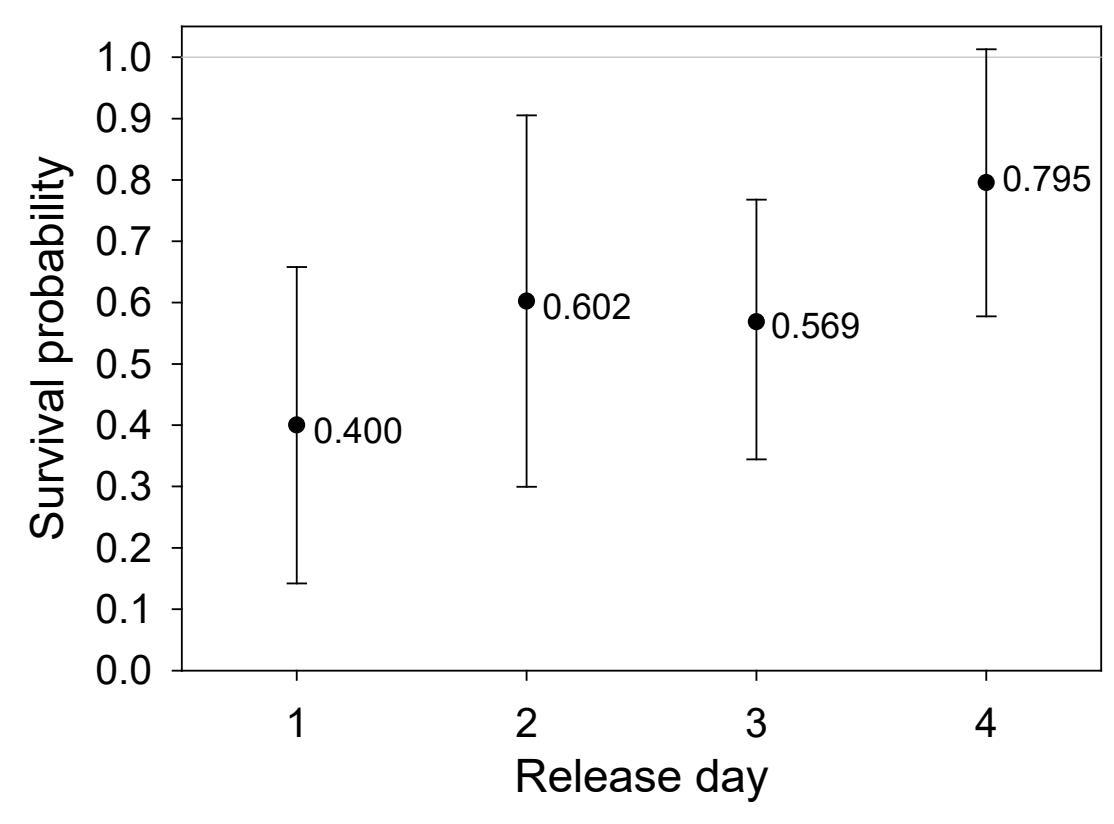

Figure 7. Estimates of Cormack-Jolly-Seber paired-release survival probability for Whooshh Fish Transport System (WFTS) survival for adult sockeye salmon released into Cle Elum Reservoir, Washington, July 14 (Release day 1) and July 17-19 (Release days 2-4), 2017. Estimates shown are for the mean sized (fork length) adult sockeye salmon tagged during this study. The gray line identifies a survival probability of 1.0. Survival estimates with confidence intervals that exceed 1.0 are indicative of single-release survival estimates that are not statistically different between release sites.

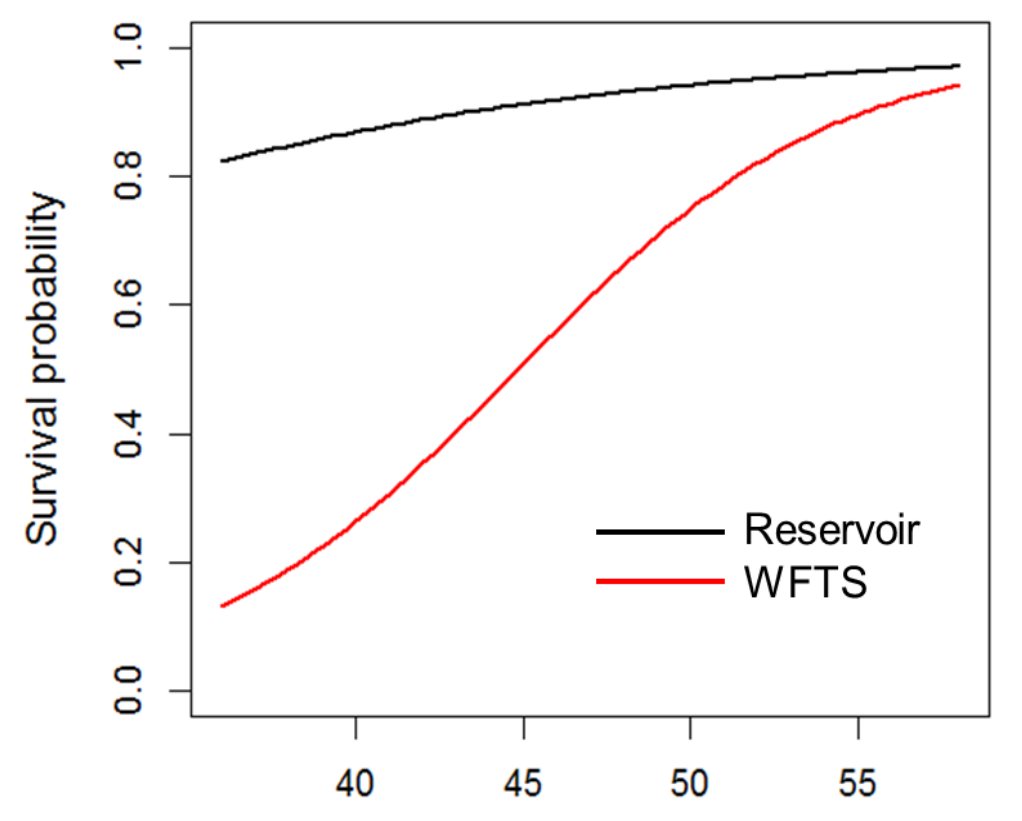

Fork length $(\mathrm{cm})$

Figure 8. Effect of fork length (in centimeters [cm]) on survival probability estimates of adult sockeye salmon passed through a Whooshh Fish Transport System (WFTS) or released at a reservoir release site (Reservoir) in Cle Elum Reservoir, Washington, July 19, 2017 (release day 4). 


\section{Behavior of Fish Released Downstream of Cle Elum Reservoir}

One of the four tagged fish released at Roza Dam moved upstream and arrived in the Cle Elum Dam tailrace $16 \mathrm{~d}$ later. That fish was released on July 17 and did not leave the Cle Elum Dam tailrace after arriving. The other three fish released at Roza Dam moved upstream initially, but stopped moving before they arrived at Cle Elum Dam. The last known locations of these fish were in the Yakima River in the Roza Dam-to-Cle Elum River mouth reach. These fish were continuously detected at their last known locations through the end of the study period. The fish that was accidentally released into the Cle Elum Dam tailrace remained at that location for the entire study period.

\section{Behavior of Fish Released into Cle Elum Reservoir}

\section{Fallback at Cle Elum Dam}

Fallback by tagged fish at Cle Elum Dam primarily occurred within $40 \mathrm{~d}$ of release (fig. 9). There was no statistical difference (Chi-squared test, $p=0.550$ ) in fallback between groups of fish released through the WFTS (18.3 percent) or at the reservoir release site (21.4 percent). Median time from release to fallback was $17.0 \mathrm{~d}$ for WFTS-passed fish and $13.8 \mathrm{~d}$ for reservoir-released fish (fig. 9). Most (69 percent) of the tagged sockeye salmon that moved downstream of Cle Elum Dam remained in the Cle Elum River mouth-to-Cle Elum Dam reach, a stretch of $12.7 \mathrm{rkm}$. The remaining fish were last detected in the Roza Dam-to-Cle Elum River mouth reach (20 percent); downstream of Roza Dam (7 percent); or in the Yakima River, upstream of the Cle Elum River mouth (4 percent).

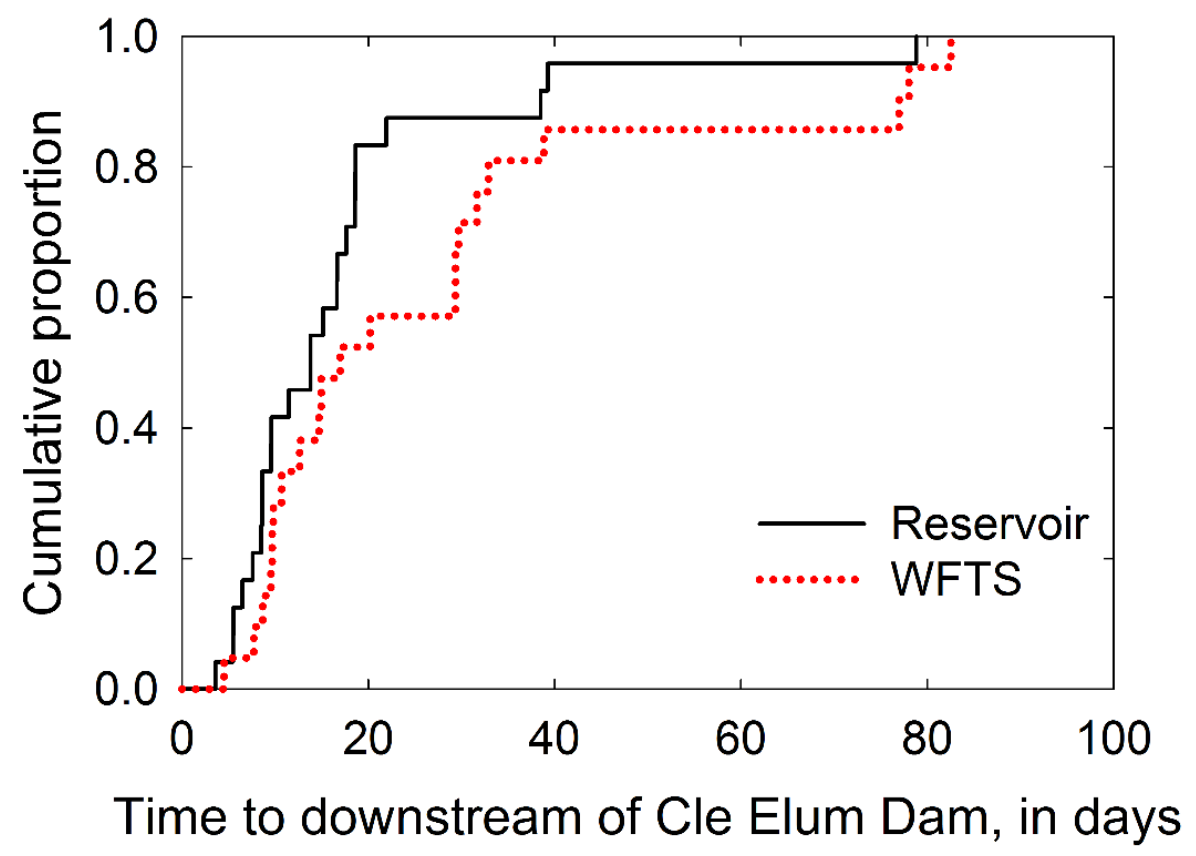

Figure 9. Cumulative timing of fallback by radio-tagged adult sockeye salmon at Cle Elum Dam, Washington, 2017. Fallback is defined as the movement of fish from the forebay to the tailrace of the dam. Tagged fish entered the reservoir at two sites -in the forebay of Cle Elum Dam through a Whooshh Fish Transport System (WFTS) and 8.8 river kilometers upstream of the dam from a fish transport truck (Reservoir). 


\section{Upstream Movement from Cle Elum Reservoir}

Tagged fish primarily moved upstream of the reservoir and entered the Cle Elum River during two distinct periods, within $20 \mathrm{~d}$ of release and 50-100 d after release (fig. 10). More than one-half (58.1 percent) of the WFTS-passed sockeye salmon moved upstream and were detected in the Cle Elum River, whereas most (83.0 percent) of the reservoir-released sockeye salmon were detected upstream of the reservoir after release (Chi-squared test; $p<0.001)$. Median time from release to first detection in the river upstream of the reservoir, was $50.6 \mathrm{~d}$ for WFTS-passed sockeye salmon and $4.3 \mathrm{~d}$ for reservoir-released fish (fig. 10). Many tagged fish made multiple upstream trips from Cle Elum Reservoir to the Cle Elum River, regardless of release site or origin (table 5). The maximum upstream movement by tagged fish generally was similar between WFTS-passed and reservoir-released sockeye salmon (fig. 11).

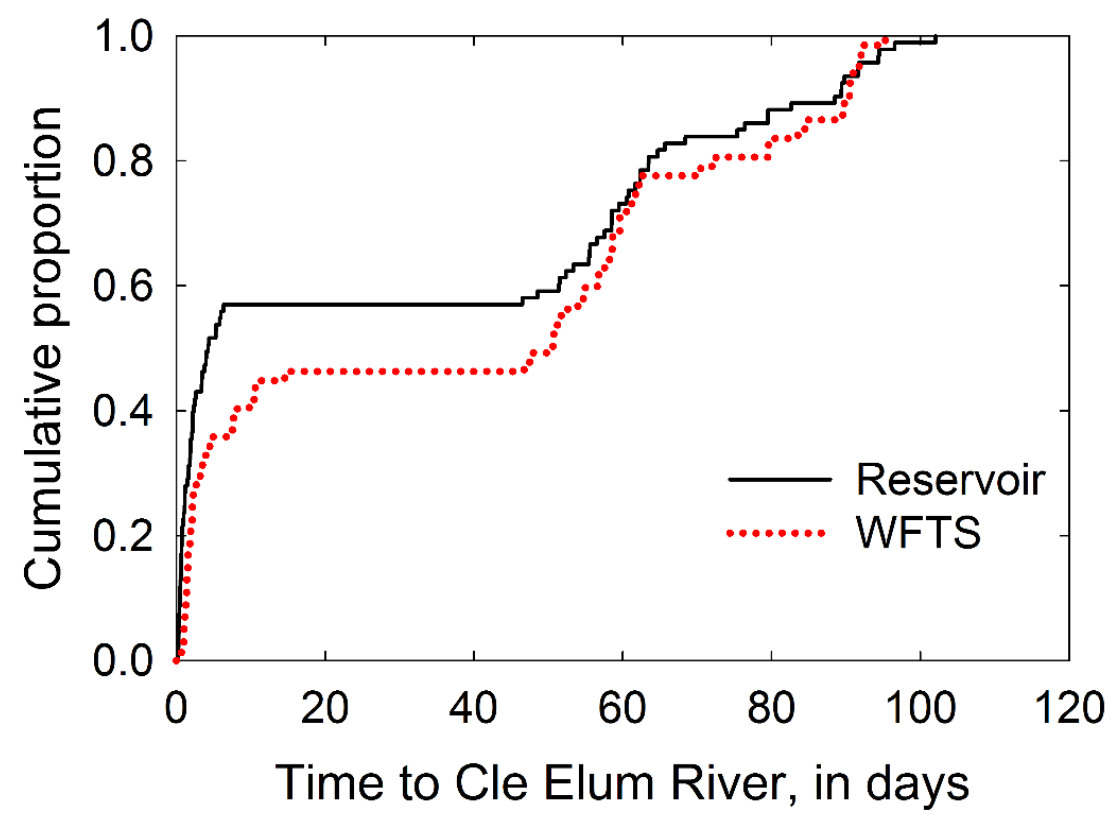

Figure 10. Cumulative timing of upstream movement by radio-tagged adult sockeye salmon from Cle Elum Reservoir to Cle Elum River, Washington, 2017. Data are shown for fish released in the reservoir from a fishhauling truck (Reservoir) or passed through a Whooshh Fish Transport System (WFTS). 
Table 5. Number of upstream trips by radio-tagged adult sockeye salmon from Cle Elum Reservoir to Cle Elum River, Washington, 2017.

[Data are shown for fish passed through a Whooshh Fish Transport System (WFTS) or released at a shoreline release site (Reservoir)]

\begin{tabular}{|c|c|c|}
\hline \multirow{2}{*}{$\begin{array}{c}\text { Number of } \\
\text { upstream trips }\end{array}$} & \multicolumn{2}{|c|}{ Release site } \\
\hline & WFTS & Reservoir \\
\hline 0 & 48 & 19 \\
\hline 1 & 44 & 48 \\
\hline 2 & 13 & 29 \\
\hline 3 & 6 & 12 \\
\hline 4 & 0 & 4 \\
\hline 5 & 2 & 0 \\
\hline 6 & 1 & 0 \\
\hline 7 & 0 & 0 \\
\hline 8 & 0 & 0 \\
\hline 9 & 0 & 0 \\
\hline 10 & 1 & 0 \\
\hline Total & 115 & 112 \\
\hline
\end{tabular}

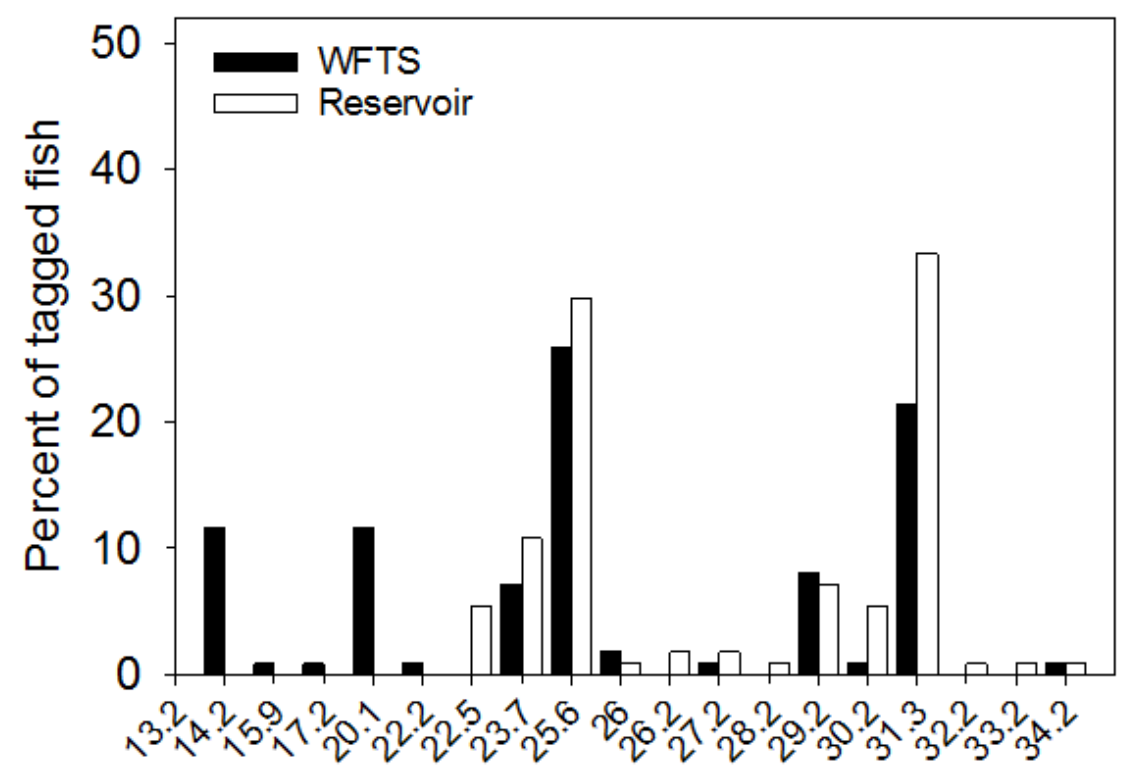

Figure 11. Percentage of tagged adult sockeye salmon as a function of the farthest upstream detection in Cle Elum River, Washington, 2017. Groups of tagged fish entered Cle Elum Reservoir in the forebay of Cle Elum Dam through a Whooshh Fish Transport System (WFTS) and 8.8 river kilometers upstream of the dam from a fish transport truck (Reservoir). 


\section{Fate During the Spawning Period}

More than one-half (57.4 percent) of the WFTS-passed sockeye salmon assigned to one of four fate categories died or moved downstream of Cle Elum Dam prior to the onset of the spawning period (table 6). In contrast, only 29.4 percent of the reservoir-released fish had mortality or fallback fates (table 6). Tagged fish that survived and remained upstream of Cle Elum Dam primarily had river fates (41.7 and 66.1 percent), whereas reservoir fates were low (4.5 percent or less; table 6).

Table 6. Number of radio-tagged adult sockeye salmon assigned to four fate groups during the spawning period (September-November) near Cle Elum Reservoir, Washington, 2017.

[Data are shown for fish passed through a Whoosh Fish Transport System (WFTS) or released at a shoreline release site (Reservoir). Numbers in parentheses are percentages of fish]

\begin{tabular}{lcc}
\hline \multicolumn{1}{c}{ Fate group } & \multicolumn{2}{c}{ Release site } \\
\cline { 2 - 3 } & WFTS & Reservoir \\
\hline Mortality & $45(39.1)$ & $9(8.0)$ \\
Fallback & $21(18.3)$ & $24(21.4)$ \\
Reservoir & $1(0.9)$ & $5(4.5)$ \\
River & $48(41.7)$ & $74(66.1)$ \\
Total & 115 & 112 \\
\hline
\end{tabular}




\section{Discussion}

In this study, a greater number of WFTS-passed sockeye died prior to the onset of spawning compared to sockeye salmon released directly into Cle Elum Reservoir from a fish hauling truck. Several factors have been identified as likely contributors to the observed mortality of WFTS-passed fish. The WFTS tube was designed to have water-misting ports that provided lubrication for fish passing through the tube at $1.8-\mathrm{m}$ intervals along the entire length of the tube. However, on release day 3 , WFTS staff discovered that the misting ports had not been properly installed (by the manufacturer) at the time of construction, and, thus, lubrication had not been available for the tagged fish that passed through the WFTS on release days 1-3. This issue was resolved for tagged fish that passed through the WFTS on release day 4. WFTS passage survival estimates were lowest on the first three release days, which suggests that the lack of lubrication may have been an important factor that influenced WFTS passage survival. Additionally, the number of adult sockeye salmon available for testing, calibration, and optimization of the WFTS was limited prior to the start of the study, so system settings were adaptively altered during the study to improve passage conditions. The release of tagged fish occurred during 4 days, which limited the ability to optimize the system over the course of the release period, relative to the original study design that would have included fish releases occurring for a month or more. The pattern of increasing WFTS passage survival probability estimates (paired releases), from a low of 0.400 for fish released on release day 1 to a high of 0.795 for fish released on release day 4 , suggests that system modifications that occurred during the release period positively influenced passage conditions for adult sockeye salmon. Additionally, previous studies with adult Chinook salmon showed that WFTS passage survival through 12.2- and 335.2-m tubes was similar to groups of control fish not exposed to WFTS passage (Fast and others, 2016).

Our results also showed an effect of fish size on WFTS passage survival. We determined that WFTS passage survival decreased with decreasing fish size (fork length). This issue was anticipated by WFTS staff because each WFTS tube is designed to optimally pass a specific range of fish sizes. If fish are too small to meet the minimum requirement of a given tube, they are unlikely to create an effective seal between the outside of their body and the inside of the WFTS tube, which could prevent them from passing or increase passage time. For this study, multiple WFTS tubes for different-sized fish were not an option and fish numbers were limited, so all fish were passed through the same WFTS tube, regardless of body size. Given these observations, it is reasonable to assume that passage survival would have been higher if multiple tubes were available, which would have ensured that each tagged fish was passed through an appropriately sized tube.

Collectively, these observations suggest that issues related to the misting system, insufficient time to optimize WFTS settings prior to and during the release window, and a smaller-than-desired size range of study fish were factors that contributed to mortality of WFTS-passed fish. Our study was able to associate variation in survival with several of these factors, which should be useful in further development of the WFTS. Furthermore, our study should facilitate future study designs that evaluate the efficacy of using the system to pass adult salmon or steelhead at a high-head dam. A WFTS can provide a means of an upstream fish-passage system at dams where more traditional methods may be ineffective or extremely expensive to install and operate. Thus, installation and evaluation of a WFTS is likely to occur at dams where these concerns exist, and observations from this study may be useful for planning and conducting effective assessments of WFTS performance. 
This study identified two additional factors that may be useful in future evaluation of the WFTS for upstream fish passage at a dam. First, we observed that tagged fish were unlikely to volitionally move from the holding gallery into the WFTS entrance. Lack of volitional entry may have been caused by several factors, including fish origin, handling-related effects from the collection, tagging, and release experience, or hydraulic conditions inside the holding gallery that discouraged volitional entry. During this study, only 2.6 percent (three fish) of the tagged fish volitionally entered the WFTS entrance from inside the holding gallery. The remaining 112 tagged fish were hand-netted and manually placed in the entrance. The lack of volitional passage delayed the release timing by a day for most WFTS-passed fish, and the increased handling may have resulted in elevated stress levels, relative to reservoir-released fish. If possible, future development of the WFTS should strive to create conditions that maximize the likelihood of volitional entry into the WFTS entrance to minimize passage delays and handling requirements that may be deleterious to fish passage. The second noteworthy observation was that WFTS-passed fish had fallback rates like those of reservoir-released fish that entered the reservoir $8.8 \mathrm{rkm}$ upstream of the dam. This was important because it showed that the location of the WFTS exit, near Cle Elum Dam, did not increase the likelihood of fallback by adult sockeye salmon. This information may be useful in future WFTS evaluations at Cle Elum Dam, if those occur.

Much behavioral data was collected that provide new insights and support observations from other studies relating to sockeye salmon responses to outplanting in Cle Elum Reservoir. Tagged fish generally seemed to show a short-term pattern of exploratory movements just after release, as indicated by high rates of upstream movement and fallback that occurred within $20 \mathrm{~d}$ of release. Fish that remained upstream of Cle Elum Dam after this period showed limited movements in August and then resumed activity, primarily by moving upstream into the Cle Elum River during SeptemberNovember.

Results from tagged sockeye salmon released at the reservoir release site provide insights into the proportion of outplanted fish that remain upstream of Cle Elum Dam during the spawning period. Single-release survival probability estimates for reservoir-released sockeye salmon averaged 0.925 in this study. This suggests that pre-spawn mortality was about 7.5 percent for sockeye salmon outplanted using the traditional trap-and-haul approach. Research in other basins has shown that pre-spawn mortality can be highly variable and substantial in some years. Keefer and others (2010) measured prespawn mortality of adult Chinook salmon on the Middle Fork of the Willamette River, Oregon, during 2004-2007. They reported overall pre-spawn mortality rates of 26.3 percent for tagged males and 37.1 percent for tagged females, but observed that these rates varied from 0.0 to 90.0 percent for some groups of fish across years (Keefer and others, 2010). Fallback also contributes to the loss of potential spawners upstream of Cle Elum Dam. In this study, 21.4 percent of the tagged fish that were released directly into Cle Elum Reservoir passed downstream of Cle Elum Dam. The loss of potential spawners to fallback is problematic for reintroduction efforts at other locations as well. In the Cowlitz River Basin during 2005-2009 and 2012, post-outplanting behavior was evaluated for adult winter steelhead, coho salmon (Oncorhynchus kisutch), and Chinook salmon upstream of Cowlitz Falls Dam (Kock and others, 2016). During these studies, 12 percent of the tagged steelhead, 8 percent of the tagged coho salmon, and 19 percent of the tagged Chinook salmon moved downstream and passed the dam prior to the onset of spawning. The authors reported that release site and origin (natural compared to hatchery) were significant predictors of fallback (Kock and others, 2016) and additional analysis of the Chinook 
salmon data identified discharge and release date as factors that also influenced fallback (Kock and others, 2018). Although origin was determined to be important in the Cowlitz River studies, research on the North Fork Toutle River showed that natural-origin steelhead and coho salmon had substantial fallback (11 percent and 15 percent, respectively) downstream of a sediment retention dam (Liedtke and others, 2013). These examples highlight the fact that outplanted salmon and steelhead populations have substantial losses through pre-spawn mortality and fallback downstream of dams that lack upstream fish-passage routes. This information can be useful for better understanding the production potential of a given population of outplanted fish.

The ability to draw inferences from the results of the Roza released fish is limited. Of these four fish, only one moved upstream and arrived at Cle Elum Dam. The remaining three fish moved upstream briefly and then stopped moving, suggesting they either died or regurgitated their transmitters. Our assessment of regurgitation rates upstream of Cle Elum Dam suggests that regurgitation is an unlikely scenario to explain why most fish in the release group failed to migrate upstream to Cle Elum Dam. It also is worth noting that the Roza released fish had the least amount of handling because they did not require the transport and release that occurred for other fish after tagging. We do not have genetic results from the two fish that were tagged on July 17, but given the fallback observed at Cle Elum Dam, those were fish that possibly had originally been released into Cle Elum Reservoir. Movement patterns between Roza Dam and Cle Elum Dam may need to be further evaluated to better understand the limited observations made during this study.

Because of logistical constraints, results from this study do not provide a comparison of survival of fish passed through a fully functional, volitional-WFTS compared to those released from a transport truck. However, our findings should be insightful for future development of the WFTS and for managing efforts to reintroduce sockeye salmon upstream of Cle Elum Dam. These results are specific to sockeye salmon that are not native to the Yakima Basin. Future evaluations may consider the inclusion of Yakima Basin sockeye salmon produced as part of the reintroduction effort. Such evaluations would provide information on the behavior and survival of fish produced within the basin and identify how these patterns differ from sockeye salmon outplanted following collection at Priest Rapids Dam. In the long term, information on sockeye salmon from the Yakima Basin may be most useful for resource managers, particularly if the reintroduction effort is successful at producing a selfsustaining population that does not require supplementation from other populations. The relative number of adult sockeye salmon that was outplanted during 2017 should also be considered. In some years, more than 10,000 adult sockeye salmon have been outplanted upstream of Cle Elum Dam, compared to 1,000 fish in 2017 (Brian Saluskin, Yakama Nation oral commun., 2017). Some behavior patterns observed during our study possibly would differ if the total population were substantially higher and resulted in increased fish density in some areas of the river or reservoir. These patterns are likely to vary among years, particularly if environmental conditions change substantially. In that regard, our assessment of environmental conditions in 2017 suggests that conditions were average when compared to conditions during 2009-2016.

In summary, the approach of using radiotelemetry and PIT tags to track fish movement patterns, and mark-recapture survival modeling to estimate survival of WFTS and reservoir-released sockeye salmon provided much information. We estimated WFTS passage survival and described post-outplanting behavior patterns of tagged sockeye salmon. The approaches used were relatively intensive and expensive, compared to other evaluation options. However, they provided detailed findings that would not otherwise be available through other means. Similar approaches are recommended for future evaluations of the WFTS for adult fish at high-head dams. 


\section{Acknowledgments}

We appreciate the efforts of many people who worked to provide funding, coordinate and plan field activities, conduct fieldwork, and provide support essential to the successful completion of this evaluation. We extend our thanks to Richard Visser and Joel Hubble (Bureau of Reclamation) for their efforts to secure funding and provide oversight as the evaluation was designed and executed. Dave Fast, Mark Johnston, Brian Saluskin and others with the Yakama Nation made significant contributions to the study design, fish collection, tagging, transport, and data collection of this evaluation. Janine Bryan, Jim Otten, and Dan Schneider (Whooshh Innovations) provided engineering, scientific, and fish-passage logistical support with Whoosh Fish Transport System fish passage over Cle Elum Dam. Finally, Peter Galbreath, Andrew Matala, and Jeremiah Newell (Columbia River InterTribal Fish Commission) worked with our staff during the spawning period to recover fish carcasses and tags, which were essential data for this study. Their participation was in conjunction with work done as part of a genetic study of the Yakama Nation sockeye reintroduction program, and included genetic stock identification analyses of the fish used in this study that permitted evaluation of the study results relative to sockeye salmon stock (Wenatchee River-origin compared to Okanogan River-origin)

\section{References Cited}

Bureau of Reclamation, 2005, Phase I assessment report - Storage dam fish passage study, Yakima Project, Washington: Bureau of Reclamation Technical Series No. PN-YDFP-001, 75 p. plus appendixes.

Bureau of Reclamation, 2007, Assessment of sockeye salmon production potential in the Cle Elum River Basin-Storage dam fish passage study_Yakima Project, Washington: Technical Series No. PN-YDFP-008, 44 p. [Also available at https://www.usbr.gov/pn/studies/fishpassage/activities/CleElum-Sockeye.pdf.]

Bureau of Reclamation, 2008, Draft Cle Elum and Bumping Lake Dams fish passage facilities planning report — Storage dams fish passage study-Yakima Project, Washington: Bureau of Reclamation, 146 p. plus appendix.

Bureau of Reclamation and Washington State Department of Ecology, 2012, Yakima River Basin integrated water resource management plan-Final programmatic environmental impact statement: Prepared by ESA and HDR Engineering, Inc., for Bureau of Reclamation.

Burnham, K.P., Anderson, D.R., White, G.C., Brownie, C., and Pollock, K.H., 1987, Design and analysis methods for fish survival experiments based on release-recapture: Bethesda, Maryland, American Fisheries Society, Monograph 5, 437 p.

Cormack, R.M., 1964, Estimates of survival from the sighting of marked animals: Biometrika, v. 51, nos. 3-4, p. 429-438, https://doi.org/10.1093/biomet/51.3-4.429.

Erikson, U., Tveit, G., and Schei, M., 2016, Evaluation of the Whooshh fish transport system for transfer of Atlantic salmon broodstock between two tanks: Report by SINTEF for Project Number 6022562, 20 p. [Also available at

https://www.whooshh.com/files/Studies/Whooshh/Transfer\%20of\%20Atlantic\%20salmon\%20with \%20WFTS_2016.pdf.]

Fast, D., Johnston, M., Bosch, B., and Bryan, J., 2016, Whooshh transport survival efficacy is reproducible across a three-year viability assessment study: Report by Yakama Nation Fisheries and Whooshh Innovations, $10 \mathrm{p}$. [Also available at https://www.whooshh.com/files/Studies/Whooshh/Roza\%20Yr\%203\%20Viability\%20Study04.18.1 7\%20final $\% 20 \% 281 \% 29$.pdf.] 
Fryer, J.K., 2017, Results of a PIT tag study at Priest Rapids Dam to assess the impact of the Whooshh fish transport system on upstream migrating sockeye salmon: Report by the Columbia River InterTribal Fish Commission for Whooshh Innovations, LLC, 26 p. [Also available at https://www.whooshh.com/files/Studies/Whooshh/Whooshh\%20sockeye\%20report\%202016\%20Fin al $\% 20 \% 281 \% 29$.pdf.]

Galbreath, P.F., Koch, I.J., Matala, A.P., Pierce, A.L., Stephenson, J.J., and Narum, S.R., 2016, 2016 annual progress report-Basinwide supplementation evaluation-BPA Project No. 2009-009-00:

Prepared by Columbia River Inter-Tribal Fish Commission for the Bonneville Power Administration, Contract No. 72525, 36 p. [Also available at https://www.cbfish.org/Document.mvc/Viewer/P154847.]

Geist, D.R., Colotelo, A.H., Linley, T.J., Wagner, K.A., and Miracle, A.L., 2014, Physical, physiological, and reproductive effects on adult fall Chinook salmon due to passage through a novel fish transport system: Report by the Pacific Northwest National Laboratory, 42 p. [Also available at https://www.whooshh.com/files/Studies/Other/PNNL\%20study\%202014.pdf.]

Geist, D.R., Colotelo, A.H., Linley, T.J., Wagner, K.A., and Miracle, A.L., 2016, Effects of a novel fish transport system on the health of adult fall Chinook salmon: Journal of Fish and Wildlife Management, v. 7, no. 2, p. 347-358, https://doi.org/10.3996/102015-JFWM-108.

Jolly, G.M., 1965, Explicit estimates from capture-recapture data with both death and immigrationstochastic model: Biometrika, v. 52, nos. 1-2, p. 225-248, https://doi.org/10.1093/biomet/52.12.225 .

Keefer, M.L., Peery, C.A., Ringe, R.R., and Bjornn, T.C., 2004, Regurgitation rates of intragastric radio transmitters by adult Chinook salmon and steelhead during upstream migration in the Columbia and Snake Rivers: North American Journal of Fisheries Management, v. 24, no. 1, p. $47-$ 54.

Keefer, M.L., Taylor, G.A., Garletts, D.F., Gauthier, G.A., Pierce, T.M., and Caudill, C.C., 2010, Prespawn mortality in adult spring Chinook salmon outplanted above barrier dams: Ecology of Freshwater Fish, v. 19, no. 3, p. 361-372, https://doi.org/10.1111/j.1600-0633.2010.00418.x.

Kock, T.J., Ekstrom, B.K., Liedtke, T.L., Serl, J.D., and Kohn, M., 2016, Behavior patterns and fates of adult steelhead, Chinook salmon, and coho salmon released into the Upper Cowlitz River Basin, 2005-2009 and 2012, Washington: U.S. Geological Survey Open-File Report 2016-1144, 36 p.

Kock, T.J., Perry, R.W., Pope, A.C., Serl, J.D., Kohn, M., and Liedtke, T.L., 2018, Responses of hatchery- and natural-origin adult spring Chinook salmon to a trap-and-haul reintroduction program: North American Journal of Fisheries Management, EarlyView, https://onlinelibrary.wiley.com/doi/abs/10.1002/nafm.10199.

Laake, J.L., 2013, RMark-An R interface for analysis of capture-recapture data with MARK: National Marine Fisheries Service, Alaska Fisheries Science Center Processed Report 2013-01, 25 p. 
Liedtke, T.L., Kock, T.J., and Rondorf, D.W., 2013, Evaluation of the behavior and movement patterns of adult coho salmon and steelhead in the North Fork Toutle River, Washington, 20052009: U.S. Geological Survey Open-File Report 2013-1290, 26 p., https://doi.org/10.3133/ofr20131290.

Matala, A.P., Narum, S.R., Galbreath, P.F., Saluskin, B., and Johnston, B., 2016. Genetic monitoring of sockeye reintroduction in Cle Elum Lake: Presentation at the 2016 Washington-British Columbia Chapter of the American Fisheries Society Meeting, Lake Chelan, Washington, accessed April 2018, at http://wabc-afs.org/w/wp-content/uploads/2016/05/03.-Matala-et-al._WA-BC-AFS.pdf.

Mesa, M.G., Gee, L.P., Weiland, L.K., and Christiansen, H.E., 2013, Physiological response of adult rainbow trout experimentally released through a unique fish conveyance device: North American Journal of Fisheries Management, v. 33, no. 6, p. 1179-1183, https://doi.org/10.1080/02755947.2013.833560.

Seber, G.A.F., 1965, A note on the multiple-recapture census: Biometrika, v. 52, nos. 1-2, p. 249-260, https://doi.org/10.1093/biomet/52.1-2.249.

Skalski, J.R., Lady, J., Townsend, R., Giorgi, A.E., Stevenson, J.R., Peven, C.M., and McDonald, R.D., 2001, Estimating in-river survival of migrating salmonid smolts using radiotelemetry: Canadian Journal of Fisheries and Aquatic Sciences, v. 58, no. 10, p. 1987-1997, https://doi.org/10.1139/f01-133.

White, G.C., and Burnham, K.P., 1999, Program MARK-Survival estimation from populations of marked animals: Bird Study, v. 46, supplement 1, p. S120-S139, https://doi.org/10.1080/00063659909477239.

Zydlewski, J., Stich, D., and Sigourney, D., 2017, Hard choices in assessing survival past dams-A comparison of single- and paired-release strategies: Canadian Journal of Fisheries and Aquatic Sciences, v. 74, no. 2, p. 178-190, https://doi.org/10.1139/cjfas-2015-0480. 
Publishing support provided by the U.S. Geological Survey

Science Publishing Network, Tacoma Publishing Service Center

For more information concerning the research in this report, contact the Director, Western Fisheries Research Center

U.S. Geological Survey

6505 NE 65th Street

Seattle, Washington 98115

https://wfrc.usgs.gov/ 
을

욤 